\title{
A Genotyping/Phenotyping Approach with Careful Clinical Monitoring to Manage the Fluoropyrimidines-Based Therapy: Clinical Cases and Systematic Review of the Literature
}

\author{
Valeria Conti ${ }^{1,2}$, Emanuela De Bellis ${ }^{3}$, Valentina Manzo ${ }^{1,2,3, *}$, Francesco Sabbatino ${ }^{1,4}$, \\ Francesco Iannello ${ }^{5}$, Fabrizio Dal Piaz ${ }^{1,2}$, Viviana Izzo 1,2 ${ }^{-1}$, Bruno Charlier ${ }^{1,2}$, \\ Berenice Stefanelli ${ }^{3}$, Martina Torsiello ${ }^{3}$, Teresa Iannaccone ${ }^{1}$, Albino Coglianese ${ }^{1}$, \\ Francesca Colucci ${ }^{3}$, Stefano Pepe ${ }^{1,4}$ and Amelia Filippelli ${ }^{1,2}$ \\ 1 Department of Medicine, Surgery and Dentistry "Scuola Medica Salernitana”, University of Salerno, \\ 84081 Baronissi, Italy; vconti@unisa.it (V.C.); fsabbatino@unisa.it (F.S.); fdalpiaz@unisa.it (F.D.P.); \\ vizzo@unisa.it (V.I.); bcharlier@unisa.it (B.C.); tiannaccone@unisa.it (T.I.); albino.cog@gmail.com (A.C.); \\ spepe@unisa.it (S.P.); afilippelli@unisa.it (A.F.) \\ 2 Clinical Pharmacology and Pharmacogenetics Unit, University Hospital “San Giovanni di Dio e Ruggi \\ d'Aragona", 84131 Salerno, Italy \\ 3 Postgraduate School in Clinical Pharmacology and Toxicology, University of Salerno, 84081 Baronissi, Italy; \\ e.debellis93@gmail.com (E.D.B.); b.stefanelli@studenti.unisa.it (B.S.); m.torsiello5@studenti.unisa.it (M.T.); \\ francescacolucci90@gmail.com (F.C.) \\ 4 Oncology Unit, University Hospital "San Giovanni di Dio e Ruggi d'Aragona", 84131 Salerno, Italy \\ 5 Postgraduate School in Clinical Pharmacology and Toxicology, University of Campania "L. Vanvitelli", \\ 80138 Naples, Italy; francesco.iannello@hotmail.it \\ * Correspondence: vmanzo@unisa.it; Tel.: +39-089-672-424
}

Received: 5 August 2020; Accepted: 1 September 2020; Published: 3 September 2020

\begin{abstract}
Fluoropyrimidines (FP) are mainly metabolised by dihydropyrimidine dehydrogenase (DPD), encoded by the DPYD gene. FP pharmacogenetics, including four DPYD polymorphisms (DPYD-PGx), is recommended to tailor the FP-based chemotherapy. These polymorphisms increase the risk of severe toxicity; thus, the DPYD-PGx should be performed prior to starting FP. Other factors influence FP safety, therefore phenotyping methods, such as the measurement of 5-fluorouracil (5-FU) clearance and DPD activity, could complement the DPYD-PGx. We describe a case series of patients in whom we performed DPYD-PGx (by real-time PCR), 5-FU clearance and a dihydrouracil/uracil ratio (as the phenotyping analysis) and a continuous clinical monitoring. Patients who had already experienced severe toxicity were then identified as carriers of DPYD variants. The plasmatic dihydrouracil/uracil ratio (by high-performance liquid chromatography (HPLC)) ranged between 1.77 and 7.38. 5-FU clearance (by ultra-HPLC with tandem mass spectrometry) was measured in 3/11 patients. In one of them, it reduced after the 5-FU dosage was halved; in the other case, it remained high despite a drastic dosage reduction. Moreover, we performed a systematic review on genotyping/phenotyping combinations used as predictive factors of FP safety. Measuring the plasmatic 5-FU clearance and/or dihydrouracil/uracil (UH2/U) ratio could improve the predictive potential of DPYD-PGx. The upfront DPYD-PGx combined with clinical monitoring and feasible phenotyping method is essential to optimising FP-based chemotherapy.
\end{abstract}

Keywords: DPD; DPYD polymorphisms; pharmacogenetics; fluoropyrimidines; personalised medicine; therapeutic drug monitoring 


\section{Introduction}

Fluoropyrimidines (FP), including 5-fluorouracil (5-FU) and its oral prodrug capecitabine, are cytotoxic antineoplastic agents belonging to the class of antimetabolites. They are commonly used to treat solid cancer types such as gastrointestinal, head-neck and breast cancers associated or not to other chemotherapeutics and both cytotoxic and biologic drugs [1,2]. The administration of the FP may cause severe, even life-threatening, adverse drug reactions (ADR), including myelosuppression, mucositis/stomatitis, diarrhoea and hand-foot syndrome (HFS). Indeed, it has been estimated that an increased risk of severe ADR (grade $>2$ ) involves $10-30 \%$ of treated patients, although these data greatly depend on the therapeutic regimen used $[1,3,4]$.

The rate-limiting step of FP catabolism is the conversion of fluorouracil to dihydrofluorouracil, which is catalysed by an enzyme called dihydropyrimidine dehydrogenase (DPD), encoded by a highly polymorphic gene (i.e., DPYD). Several single-nucleotide polymorphisms (SNPs) have been associated to an alteration of the DPYD sequence, and some of them may determine a partial or complete DPD deficiency, leading to FP severe toxicity [1].

The Clinical Pharmacogenetics Implementation Consortium (CPIC) and the Dutch Pharmacogenetics Working Group (DPWG) [5,6] have published guidelines for FP dosing based on the pharmacogenetic testing of four DPYD polymorphisms that are DPYD*2A (rs3918290), DPYD*13 (rs55886062), DPYD c.2846A>T (rs67376798) and c.1129-5923C >G (rs75017182 and HapB3). The latter is the most common variant, with $\sim 4 \%$ allelic frequency; the $D P Y D^{*} 2 A, c .2846 A>T$ and $D P Y D^{*} 13$ are present in $\sim 2.0 \%, 1.4 \%$ and $0.1 \%$, respectively, of Caucasian patients [5]. Recently, a new polymorphism, DPYD*6 (rs1801160), has been associated with both gastrointestinal and haematological FP-ADR [7].

Notably, other DPYD genetic variants may lead to dangerous clinical consequences, although their frequency is very low $[5,6,8]$.

With the main aim of reducing the risk of severe FP-induced toxicity, the CPIC and DPWG have implemented a gene activity score (DPYD-AS), which ranges from 0 (complete DPD deficiency) to 2 (normal DPD activity). In patients who are homozygous for one or more of the aforementioned SNPs, the recommendation is to avoid the use of FP. However, if alternative drugs are not considered a suitable option, the FP dosage should be markedly reduced while establishing a therapeutic drug-monitoring (TDM) approach. Patients who are heterozygous should receive a 50\% dose reduction at the first cycle of chemotherapy, followed by a titration dose, while monitoring the patient's clinical conditions and possibly performing TDM $[5,6]$.

However, it has been estimated that $30-50 \%$ of the patients experience severe ADR, despite not having a DPD deficit associated with such DPYD polymorphisms. In fact, there are several factors, including comorbidities, polytherapy, other variants in the DPYD and other genes, that can play an important role [9]. Besides DPYD polymorphisms, two SNPs in the 5,10-methylenetetrahydrofolate reductase (MTHFR) gene [10] and a tandem repeat in the thymidylate synthase enhancer region (TYMS-TSER) could concur in predicting FP-related toxicity [11]. Moreover, a SNP in glutathione S-transferase-p1 (GSTP1) has been suggested as a genetic factor able to influence the response to oxaliplatin, a drug frequently administered with FP [12].

Several strategies complementing the DPYD pharmacogenetics (DPYD-PGx) have been proposed to prevent FP-related severe ADR associated with DPD deficit. Among others, the measurement of the plasmatic dihydrouracil/uracil ratio $\left(\mathrm{UH}_{2} / \mathrm{U}\right)$ and the monitoring of 5-FU clearance are considered valid approaches $[13,14]$. Here, we reported clinical cases in whom a combined genotyping/phenotyping approach, together with careful clinical monitoring was used to optimise the FP-based treatment. In addition, we performed a systematic review of the literature concerning the use of DPYD-PGx, together with phenotyping methods to personalise such chemotherapy. 


\section{Materials and Methods}

\subsection{Case Series}

We describe the cases of eleven oncological patients of the Campania Region (Italy) treated with FP-based chemotherapy. They were enrolled in an ongoing study (ethics committee approval n. 4_r.p.s.o.) whose main aim was to investigate the association between DPYD SNPs and other genetic variants with FP-related severe toxicity. To manage the therapy of these eleven patients, we used a combined genotyping/phenotyping approach with clinical monitoring.

A careful clinical monitoring was carried out by interviewing patients and checking the results of their blood counts at each cycle of chemotherapy. The ADR were recorded and graded according to the Common Terminology Criteria for Adverse Events (CTC-AE) version 5.0 [15]. The Response evaluation criteria in solid tumors (RECIST) were used to assess the treatment response [16].

All enrolled patients were genotyped for the recommended DPYD SNPs (DPYD*2A, DPYD*13, DPYD 2846A > T and c.1129-5923C > G) as part of the clinical practice. Besides this pharmacogenetic testing (DPYD-PGx) performed by real-time PCR with allelic discrimination, the SNPs MTHFR-C677T and -A1298C were analysed using pyrosequencing technology and the TYMS-TSER variant by classical PCR and agarose gel-based electrophoresis.

A phenotyping analysis was carried out by determining the plasmatic UH2/U ratio, as an indirect measurement of DPD activity, using high-performance liquid chromatography (HPLC) [17]. Moreover, in three patients, a 5-FU pharmacokinetic analysis was also performed to determine the plasmatic 5-FU clearance by using ultra-high-performance liquid chromatography combined with tandem mass spectrometry (UHPLC-MS/MS) [18]. Written informed consent was obtained from the patients for participation in the study, as well as publication of their data.

\subsection{Systematic Review}

\subsubsection{Search Strategy}

A systematic review was performed using the PubMed, Scopus and Cochrane databases from inception to 3 July 2020. The following keywords and Medical Subject Headings (MeSH) terms were used for the search: DPYD polymorphism, dihydropyrimidine dehydrogenase deficiency, 5-FU clearance and dihydrouracil/uracil ratio.

The Preferred Reporting Items for Systematic Reviews and Meta-analyses (PRISMA) guidelines were applied [19]. A total of 1932 studies were retrieved from the searched databases. After the removal of duplicates and then article types such as reviews, metanalyses, case reports, etc., 112 articles were screened. Afterward, considering the inclusion and exclusion criteria, 22 articles were included in the analysis. The flowchart of the literature screening is reported in Figure 1. 

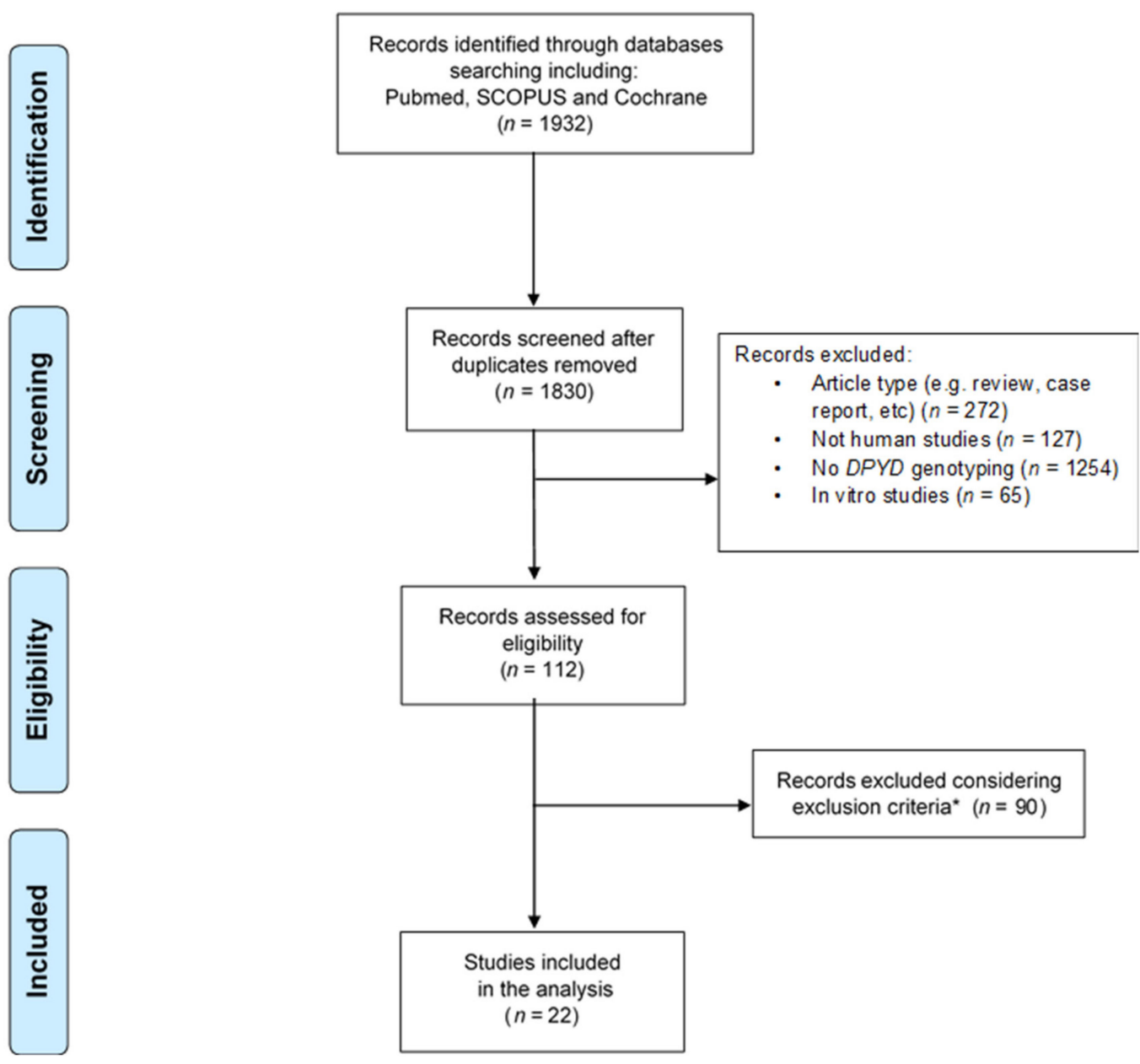

Figure 1. Flowchart of the databases searched. * Exclusion criteria: (1) studies not including at least one of the four recommended DPYD polymorphisms and (2) other study designs (e.g., allelic frequencies estimation, no patients and methods for genotyping).

\subsubsection{Eligibility Criteria}

The search was limited to studies conducted in human beings and published in the English language. Both observational and randomised clinical studies were eligible. Only the studies enrolling patients treated with FP and showing results of DPYD-PGx, analysing at least one of the four SNPs recommended in the CPIC and DPWG guidelines, have been included in the analysis.

\subsubsection{Article Selection}

First, articles were selected by reading their titles and abstracts. Then, the full text of all articles considered eligible was read. The authors (Valeria Conti and Berenice Stefanelli) carried out this work independently and discussed when there was a disagreement about the relevance of an article.

\subsubsection{Data Extraction}

Clinical, genetic and biochemical data were extracted from the articles. The factors considered were: study design, sample size, DPYD genotyping combined with phenotyping methods and/or clinical monitoring. 


\section{Results}

\subsection{Cases Presentation}

Case 1 was a Caucasian 55-year-old male former smoker with a history of hypertension. The patient had stage IV colorectal adenocarcinoma with metastases in the lymph nodes, lungs, liver and kidneys. The tumour mutational profile identified no mutations in the KRAS, NRAS or BRAF genes. The patient was treated with the combination of 5-FU, leucovorin and oxaliplatin (FOLFOX6) regimen, plus cetuximab. After three cycles of chemotherapy, the patient reported grade 1 thrombocytopenia and paraesthesia; grade 2 stomatitis, rash and leukopenia and grade 3 neutropenia and mucositis.

A post-therapeutic DPYD-PGx was performed, revealing that the patient was heterozygous for $D P Y D^{*} 2 A$. Moreover, the patient was homozygous (TT) for MTHFR-C677T, homozygous TYMS-TSER-2R/2R and homozygous (AA) for GSTP1-A313G. The plasmatic UH2/U ratio was 4.52. Based on these results and the reported toxicity, both the 5-FU and cetuximab doses were reduced. Specifically, the total dosage of 5-FU was reduced to 50\%, according to the CPIC and DPWG guidelines.

At the fourth cycle of therapy, the pharmacokinetic analysis revealed a trough 5-FU plasma concentration of $950 \mathrm{ng} / \mathrm{mL}$. The CT scan demonstrated an overall stable disease, according to the RECIST criteria v1.1. The patient was still treated with the same doses of 5-FU. At the sixth cycle of therapy, the 5-FU plasma concentration was $400 \mathrm{ng} / \mathrm{mL}$. The following cycles (fifth to eighth) of chemotherapy were administered at the same drug doses. A new CT scan demonstrated no evidence of disease progression. The ADR were grade 1 leukopenia, neutropenia, thrombocytopenia and mucositis and grade 2 HFS. Following a further two cycles of therapy, the reported ADR were grade 1 paraesthesia, erythematous maculopapular rash and grade 2 cutaneous and mucous fissures. Lastly, following a further two treatment cycles, a new CT scan showed disease progression. The treatment was stopped, and the administration of a new chemotherapeutic regimen was planned. Sadly, the patient died before starting a second line of treatment.

Case 2 was a Caucasian 48-year-old male with no comorbidity. He had stage IV colorectal adenocarcinoma with metastases in the lymph nodes and liver. The tumour mutational profile highlighted the presence of a KRAS mutation; thus, a treatment with the FOLFOX6 regimen plus bevacizumab was planned. A pretherapeutic DPYD-PGx was requested, and the patient was identified as DPYD*2A heterozygous. In addition, he was wild type for MTHFR-C677T and MTHFR-A1298C, heterozygous TYMS TSER-2R/3R and homozygous (GG) for GSTP1-A313G. The plasmatic UH2/U ratio was 3.22. Based on these results, a $50 \%$ dose reduction of 5-FU was planned for the first cycle of FOLFOX administration, according to the CPIC and DPWG guidelines. After the first cycle of treatment, the plasmatic 5-FU clearance was $474 \mathrm{ng} / \mathrm{mL}$. Following three cycles of therapy, a stable disease was found, according to the RECIST criteria v1.1, and no adverse events were reported. The patient was still treated with the same doses of chemotherapeutic agents for an additional seven cycles of therapy. Grade 1 paraesthesia and mucositis and grade 2 HFS but no severe ADR were reported, and the CT scan demonstrated a stable disease. Afterward, the patient was treated up to the twelfth cycle with a FOLFOX regimen plus bevacizumab, still obtaining, at revaluation, a stable disease. Then, he was a candidate for a maintenance therapy with capecitabine plus bevacizumab. Following 16 cycles of this therapy, the patient reported grade 1 paraesthesia and mucositis, and no severe ADR were recorded.

Case 3 was a Caucasian 60-year-old male former smoker with no comorbidities. He had stage IV rectal adenocarcinoma with liver metastases. The tumour mutational profile did not identify mutations in either KRAS, NRAS or BRAF. Based on the tumour profile and stage, the patient was a candidate for a FOLFOX regimen plus cetuximab. A pretherapeutic DPYD-PGx was performed, and the patient was found heterozygous for DPYD c2846A>T SNP. Therefore, according to the CPIC and DPWG guidelines, he started chemotherapy with a 50\% dose reduction of 5-FU. Moreover, he was homozygous (TT) for MTHFR-C677T, heterozygous TYMS TSER-2R/3R and heterozygous for GSTP1-A313G. The plasmatic $\mathrm{UH} 2 / \mathrm{U}$ ratio was 1.77 . 
A grade 2 diffuse maculopapular rash was reported, and, based on such an ADR, the dose of cetuximab was also reduced to $50 \%$ for the second cycle of therapy. The plasmatic 5-FU clearance was $811 \mathrm{ng} / \mathrm{mL}$ - still high, notwithstanding the 5-FU dose reduction. The patient reported no improvement of the skin rash and grade 2 diarrhoea. At the third cycle of therapy with the same drugs doses, the 5-FU plasma level was $1093 \mathrm{ng} / \mathrm{mL}$. Grade 1 nausea and grade 3 diarrhoea were reported. Based on these results, the $5-\mathrm{FU}$ dose was further reduced by an additional $10 \%$ at the fourth cycle of therapy. However, the 5-FU plasma concentration was still high $(1048 \mathrm{ng} / \mathrm{mL})$, and grade 4 diarrhoea was reported. Hence, it was decided not to administer 5-FU in a continuous infusion, leaving the administration of 5-FU in bolus. Nevertheless, the 5-FU plasma concentration was still high (i.e., $934 \mathrm{ng} / \mathrm{mL}$ ), and grade 3 diarrhoea was reported.

A CT scan showed a partial response according to the RECIST criteria with a reduction of hepatic lesions. It was decided to carry out a further cycle with oxaliplatin plus cetuximab.

After this cycle, the hepatic lesions were resected. After one month from surgery, a CT scan demonstrated the development of a new hepatic lesion. The patient was a candidate to start a new treatment with 5-FU plus irinotecan as a modified 5-FU, leucovorin and irinotecan (FOLFIRI) regimen, since 5-FU was administered with a 50\% dose reduction and without continuous infusion. The patient performed six cycles of FOLFIRI plus bevacizumab. Grade 3 diarrhoea was reported. As a consequence, the 5-FU administration was stopped, and only irinotecan and bevacizumab were further administered. After four cycles of this treatment, the CT scan demonstrated a progression of the disease. The patient died after 11.2 months from starting treatment with irinotecan plus bevacizumab.

Tables 1 and 2 report the main characteristics and the occurrence of grade $\geq 3$ ADR of 3/11 and $8 / 11$ clinical cases, respectively. Table 1 describes three clinical cases for whom either pretherapeutic DPYD-PGx or post-therapeutic DPYD-PGx were performed. As phenotypic characteristics, the UH2/U ratio values and plasmatic 5-FU clearance were reported. 
Table 1. Reports of the main characteristics of three patients with the occurrence of grade $\geq 3$ ADR.

\begin{tabular}{|c|c|c|c|c|c|c|c|c|c|c|c|c|}
\hline $\mathrm{Pt}$ & Sex & $\begin{array}{c}\text { Age } \\
\text { (years) }\end{array}$ & $\begin{array}{l}\text { Tumor } \\
\text { Type and } \\
\text { Stage }\end{array}$ & $\begin{array}{l}\text { Chemotherapy } \\
\text { Regimen }\end{array}$ & $\begin{array}{l}\text { Pre-Therapeutic } \\
\text { DPYD-PGx }\end{array}$ & $\begin{array}{c}\text { Post-Therapeutic } \\
\text { DPYD-PGx }\end{array}$ & $\begin{array}{c}\text { DPYD } \\
\text { Genotype }\end{array}$ & $\begin{array}{l}\text { UH2/U } \\
\text { Ratio }\end{array}$ & 5-FU Dosage & $\begin{array}{c}\text { 5-FU } \\
\text { Clearance }\end{array}$ & $\mathrm{ADR} \geq 3$ & $\begin{array}{c}\text { Total } \\
\text { Toxicity }\end{array}$ \\
\hline 1 & M & 55 & $\begin{array}{c}\text { CRC } \\
\text { (metastatic) }\end{array}$ & $\begin{array}{l}\text { Folfox plus } \\
\text { cetuximab }\end{array}$ & / & Yes (C4) & $\begin{array}{c}\text { Heterozygous } \\
\text { for } \\
D P Y D^{*} 2 \mathrm{~A}\end{array}$ & 4.52 & $\begin{array}{l}\text { C1-C3: } 100 \% \\
\text { C4-C6: } 50 \%\end{array}$ & $\begin{array}{c}950 \mathrm{ng} / \mathrm{mL} \\
(\mathrm{C} 4) \\
400 \mathrm{ng} / \mathrm{mL} \\
(\mathrm{C} 6)\end{array}$ & $\begin{array}{l}\text { G3 mucositis } \\
\text { (C3) G3 } \\
\text { neutropenia } \\
\text { (C3) } \\
\text { (neuthrophils: } \\
830.58 / \mathrm{mm}^{3} \text { ) }\end{array}$ & 7 \\
\hline 2 & M & 48 & $\begin{array}{c}\text { CRC } \\
\text { (metastatic) }\end{array}$ & $\begin{array}{c}\text { Folfox plus } \\
\text { bevacizumab }\end{array}$ & Yes & / & $\begin{array}{c}\text { Heterozygous } \\
\text { for } \\
D P Y D^{*} 2 \mathrm{~A}\end{array}$ & 3.22 & C1-C8: 50\% & $\begin{array}{l}474 \mathrm{ng} / \mathrm{mL} \\
\text { (C1) }\end{array}$ & / & 6 \\
\hline 3 & M & 60 & $\begin{array}{c}\text { Rectal } \\
\text { cancer } \\
\text { (metastatic) }\end{array}$ & $\begin{array}{l}\text { Folfox plus } \\
\text { cetuximab) }\end{array}$ & Yes & / & $\begin{array}{c}\text { Heterozygous } \\
\text { for } \\
\text { c. } 2846 \mathrm{~A}>\mathrm{T}\end{array}$ & 1.77 & $\begin{array}{l}\text { C1-C3: } 50 \% \\
\text { C4: } 40 \% \\
\text { C5-C6: } 40 \% \\
\text { (only bolus) }\end{array}$ & $\begin{array}{c}811 \mathrm{ng} / \mathrm{mL} \\
(\mathrm{C} 2) 1093 \\
\mathrm{ng} / \mathrm{mL}(\mathrm{C} 3) \\
1048 \mathrm{ng} / \mathrm{mL} \\
(\mathrm{C} 4) 934 \\
\mathrm{ng} / \mathrm{mL}(\mathrm{C} 5)\end{array}$ & $\begin{array}{c}\text { G3 diarrhoea } \\
\text { (C3) } \\
\text { G4 diarrhoea } \\
\text { (C4) } \\
\text { G3 diarrhoea } \\
\text { (C5) }\end{array}$ & 3 \\
\hline
\end{tabular}

$\mathrm{Pt}$, patient; M, male; CRC, colorectal cancer; FOLFOX, 5-fluorouracil plus leucovorin plus oxaliplatin; DPYD-PGx, DPYD pharmacogenetics; 5-FU, 5-fluorouracil; C, cycle; plasmatic UH2/U ratio, dihydrouracil/uracil ratio; $A D R$, adverse drug reaction; $G$, grade and total toxicity, number of ADR regardless of the grade of severity. 
Table 2. Reports of 8 clinical cases for whom either pretherapeutic DPYD-PGx or post-therapeutic DPYD-PGx were performed. As phenotypic characteristics, the $\mathrm{UH} 2 / \mathrm{U}$ ratio values were reported.

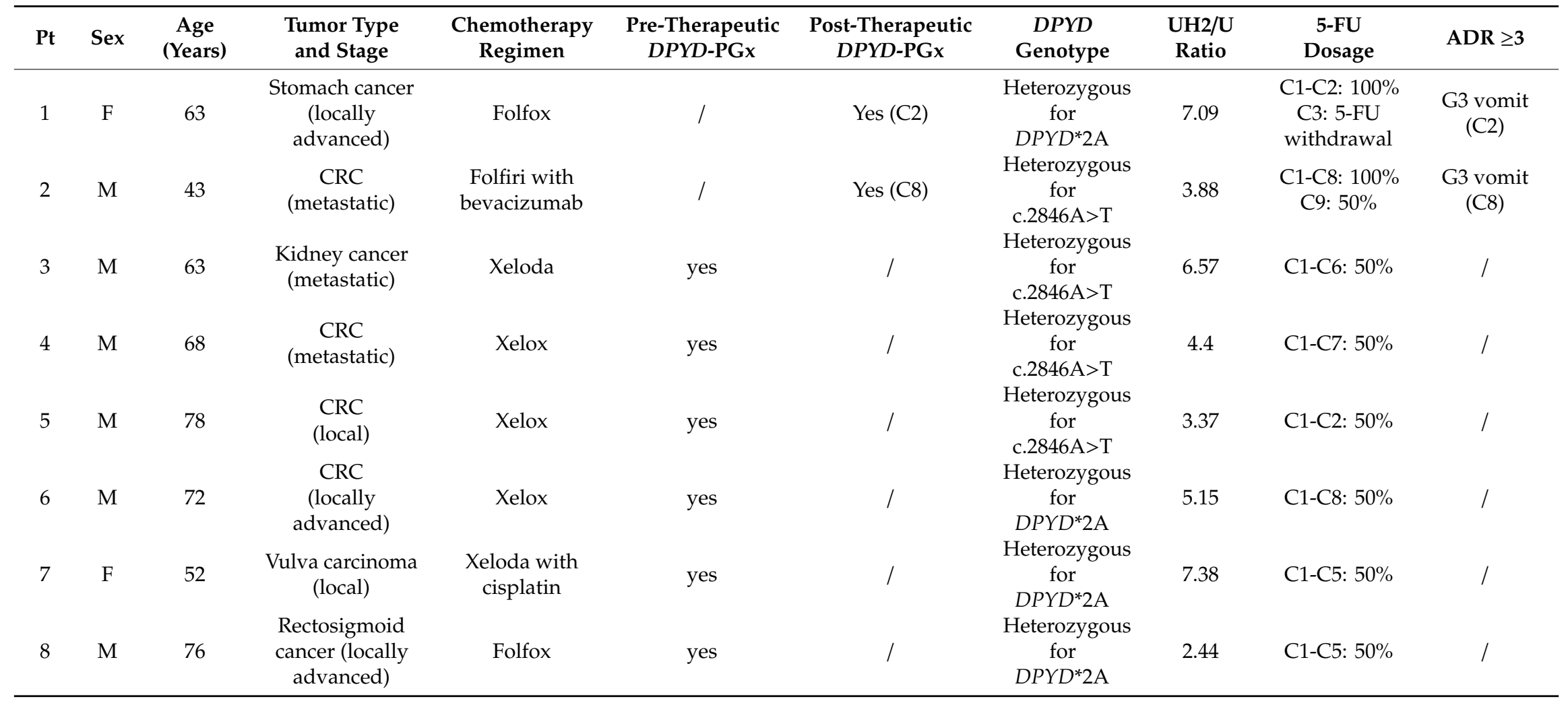

Pt, patient; M, male; F, female; CRC, ColoRectal Cancer; FOLFOX, 5-Fluorouracil plus leucovorin plus oxaliplatin; FOLFIRI, 5-Fluorouracil plus leucovorin plus irinotecan; XELOX, 
A pretherapeutic DPYD-PGx was performed in two out of three cases, while one patient (case 1) had already started chemotherapy before requesting DPYD-PGx. Importantly, the patients were monitored during all treatment cycles.

Besides these three clinical cases, the history of other eight patients is briefly reported below, and their main characteristics are listed in Table 2.

All subjects were monitored for at least four treatment cycles. In two out of eight subjects, the DPYD-PGx was required after the occurrence of severe toxicity (post-therapeutic DPYD-PGx), while in six out of eight, pharmacogenetic testing was performed before the treatment started (pretherapeutic DPYD-PGx). All patients were identified as carriers of DPYD variants-precisely, four out of eight were $D P Y D^{*} 2 A$ heterozygous, and four out of eight were DPYD c.2846 heterozygous.

The two patients for whom the DPYD-PGx was performed after 5-FU administration experienced grade $3 \mathrm{ADR}$ with a different timing, and both were then revealed as DPYD-variant carriers. More in detail, one patient with stage III gastric cancer, treated with FOLFOX, suffered from grade 3 vomit after the second cycle; he was then identified as $D P Y D^{*} 2 A$ heterozygous and continued to be treated only with oxaliplatin. Moreover, the patient was homozygous (TT) for MTHFR-C677T, homozygous TYMS TSER-3R/3R and homozygous (AA) for GSTP1-A313G.

The other one with stage IV colon cancer, treated with FOLFIRI plus bevacizumab, showed grade 3 vomit after the eighth cycle of chemotherapy. The patient was identified as DPYD c.2846 heterozygous, and the 5-FU dosage was halved. With regards to the other SNPs, the patient was homozygous (TT) for MTHFR-C677T, heterozygous TYMS TSER-2R/3R and wild type for UGT1A1*28 SNP. The latter polymorphism is routinely analysed in patients treated with irinotecan.

Conversely, in the other patients, a pretherapeutic DPYD-PGx was performed; thus they were treated with a starting halved dose of 5-FU, and no severe ADR were reported.

\subsection{Systematic Review}

A systematic review was performed to analyse the studies investigating the variability of responses to FP-based chemotherapy by DPYD genotyping combined with phenotyping methods and/or clinical monitoring.

Of the potential 112 articles assessed for eligibility, after considering the inclusion and exclusion criteria, 22 studies were included in the analysis [20-41]. Table 3 shows such studies subdivided with respect to the analysed DPYD polymorphisms (DPYD-PGx), the used phenotyping methods and the presence of clinical monitoring. A DPYD-PGx/clinical monitoring combination was present in 11 , and $D P Y D-P G x /$ phenotyping in three, surveys. A DPYD-PGx/phenotyping/clinical monitoring combined approach was made in eight studies (Table 3).

Among the studies with a DPYD-PGx/clinical monitoring combination, five out of eleven studies confirmed the importance of DPYD variants in predicting FP-related toxicity, although a too-short clinical monitoring was performed (only two treatment cycles) [21,23,29,31,39]. Two studies [24,34] analysed only DPYD 2 A of the DPYD SNPs currently recommended. The first confirmed a strong association between DPYD*2A and a severe and potentially fatal toxicity [24]. The second did not analyse this type of association because of the too-low DPYD*2A allelic frequency found in the study population [34].

Lee et al., by testing 2886 patients, reported a significant association between DPYD*2A and DPYD c.2846A $>$ T and grade $\geq 3$ FP ADR [26]. Similarly, Cremolini et al., in a large cohort of colon cancer patients who were treated with FOLFIRI or FOLFOXIRI plus bevacizumab, demonstrated that DPYD*2A and DPYD c.2846A $>$ T predicted FP-associated clinically relevant ADR [36]. Iachetta et al. analysed 668 out of 1827 patients enrolled in their study. The authors, first, confirmed the clinical relevance of DPYD c.2846A $>$ T and DPYD*13 in predicting FP safety. Second, they found a significant association between DPYD*6 and severe neutropenia. Notably, no patients carrying DPYD*2A (1.7\%) had started a FP-based treatment [38]. Negarandeh et al. screened the presence of DPYD c.2846A $>$ T, DPYD*6 and DPYD*2A in a population of 73 Iranian patients. DPYD c.2846A $>$ T and DPYD*6 were not found in the 
patient population analysed. However, a high allelic frequency for DPYD*2A (5.5\%) was reported. Surprisingly, Negarandeh et al. did not find any significant association between DPYD*2A and severe toxicity [40].

A DPYD-PGx/phenotyping combined approach was performed in three studies that underlined the importance of complementing the DPYD-PGx with a phenotyping analysis. Gentile et al., by measuring the 5-FUDR (degradation rate) in peripheral blood mononuclear cells (PBMCs) utilising HPLC with MS/MS, found a significant correlation between several polymorphisms, including DPYD*2A and DPYD c.2846A $>$ T, and this phenotyping marker [27]. Jacobs et al. determined 5-FU clearance in the plasma of patients treated with capecitabine, finding that the presence of DPYD*2A led to a $21.5 \%$ reduction in 5-FU elimination. Pallet et al. evaluated an approach based on the combination of the plasmatic UH2/U ratio and uracil concentration with genotyping of the four recommended DPYD SNPs. The main finding of this study was that complementing the DPYD-PGx with the plasmatic UH2/U ratio increased the possibility to identify patients at higher risks of severe FP-related toxicity [41]. Among the studies that performed a DPYD-PGx/phenotyping approach with clinical monitoring, four out of eight studies reported information about FP-related ADR until a maximum of three treatment cycles.

Joerger et al. confirmed the importance of DPYD genotyping to identify patients at high risks of severe FP-related toxicity. Unfortunately, because of the low sample size of the study, they did not show conclusive results about the usefulness of plasmatic 5-FU clearance determination in improving the predictive potential of DPYD-PGx [28].

Galarza et al. found that salivary and plasmatic UH2 concentrations were inversely correlated with the ADR grade. However, given the low number of patients enrolled in the study, no DPYD variant allele carriers were identified [30].

Boisdron et al. conducted a phase II study in 85 patients to test the efficacy of a pharmacogenetic-guiding dosing approach combined with the UH2/U ratio measurement. Despite a very large increase in drug dosages, a low incidence of severe ADR was shown in patients who used a guiding dosing approach. However, also in this case, it was not possible to conclude if this phenotyping analysis enhanced the predictability of DPYD genotyping because of the low sample size of the study [32]. Etienne et al. failed to demonstrate a correlation between DPYD variants and the plasmatic UH2/U ratio values. The authors concluded that only an extension of the genetic panel may improve the performance of DPYD-PGx for predicting severe and life-threatening ADR associated with capecitabine [33].

Kuilenburg et al. measured the UH2/U ratio in PBMCs as an indirect assessment of DPYD activity. They demonstrated that patients with a low DPD activity experienced a more rapid onset of toxicity as compared to those with a normal enzymatic activity. Moreover, grade 4 neutropenia occurred in a substantial percentage (55\%) of the patients with a decreased DPD activity as compared to that $(13 \%)$ of subjects with a normal DPD activity. Notably, eleven out of fourteen patients suffering from severe ADR with a decreased enzymatic activity were identified as carriers of DPYD polymorphisms. In particular, six, four and one out of eleven patients carried DPYD*2A, DPYD*9A and DPYD*6 in homozygosis, respectively [20]. Kristensen et al. also showed a significant correlation between the plasmatic UH2/U ratio and the presence of DPYD*2A [22].

Finally, in a prospective study, Henricks et al. analysed all the four recommended DPYD SNPs and performed two phenotyping tests by measuring the UH2/U ratio in PBMCs and plasmatic 5-FU pharmacokinetics (PK) by UHPLC-MS/MS. The patients carrying DPYD c.1236G $>$ A and DPYD c.2846A $>$ T were more likely to manifest FP-related severe toxicity as compared to wild-type subjects. In addition, the mean DPD enzyme activity was significantly lower in patients bearing these two genetic variants, as well as DPYD*2A, as compared to other patients. Only one patient carrying DPYD*13 showed a $60 \%$ DPD activity reduction. This patient was treated with a reduced 5-FU dosage for three treatment cycles, and no severe ADR occurred. Based on these results, the authors confirmed that a dose reduction of $50 \%$ in DPYD*2A and DPYD*13 carriers is appropriate, as issued in the PGx guidelines [35]. 
Table 3. The table reports the studies included in the systematic review and subdivided into three groups: DPYD-PGx/clinical monitoring combination, DPYD-PGx/phenotyping and DPYD-PGx/phenotyping/clinical monitoring. Abbreviations: PBMC, peripheral blood mononuclear cells; HPLC-UV, high-performance liquid chromatography-UV detector; LC-MS/MS, liquid chromatography-tandem mass spectrometry; 5-FUDR, 5-FU degradation rate; UHPLC-MS/MS, ultra-high-performance liquid chromatography-tandem mass spectrometry; PK, pharmacokinetics; FP, fluoropyrimidines; DPD, dihydropyrimidine dehydrogenase; $\mathrm{UH} 2 / \mathrm{U}$ ratio, dihydrouracil/uracil ratio and AAS, atomic absorption spectrometry.

\begin{tabular}{|c|c|c|c|c|c|}
\hline $\begin{array}{l}\text { First Author's Name } \\
\text { (Published Year) }\end{array}$ & $\begin{array}{l}\text { Enrolled } \\
\text { Patients (n) }\end{array}$ & Outcomes & $\begin{array}{l}\text { DPYD-PGx/Clinical } \\
\text { Monitoring }\end{array}$ & $\begin{array}{l}\text { DPYD-PGx/ } \\
\text { Phenotyping }\end{array}$ & $\begin{array}{c}\text { DPYD-PGx/Phenotyping/Clinical } \\
\text { Monitoring }\end{array}$ \\
\hline Kuilenburg et al. (2000) [20] & 37 & $\begin{array}{l}D P D \text { activity and overall toxicity; } \\
D P Y D \text { genotyping in patients with } \\
\text { reduced DPD activity. }\end{array}$ & & & $\begin{array}{l}D P Y D^{*} 2 \mathrm{~A}, \text { c. } 2846 \mathrm{~A}>\mathrm{T}, \mathrm{DPYD} \mathrm{D}^{*} 6 \\
\text { DPYD*9A, c.496A }>\mathrm{G} / \mathrm{UH} 2 / \mathrm{U} \text { ratio } \\
\text { in PBMC/ADR until two treatment } \\
\text { months. }\end{array}$ \\
\hline Schwab et al. (2008) [21] & 683 & $\begin{array}{l}\text { Overall toxicity; DPYD, TYMS, } \\
\text { MTHFR genotyping; sequencing of } \\
\text { DPYD exome; influence of sex and } \\
\text { promoter methylation on DPD } \\
\text { expression in human liver. }\end{array}$ & $\begin{array}{c}D P Y D^{*} 2 \mathrm{~A}, \mathrm{c} .2846 \mathrm{~A}>\mathrm{T}, \\
\text { c. } 623 \mathrm{G}>\mathrm{T}, D P Y D^{*} 4, \\
D P Y D^{*} 6 \text {, and c. } 2858 \mathrm{G}>\mathrm{C} / \\
\text { ADR reported until the } \\
\text { second cycle of treatment. }\end{array}$ & & \\
\hline Kristensen et al.(2010) [22] & 68 & $\begin{array}{l}\text { Relationship between } \mathrm{UH}_{2} / \mathrm{U} \\
\text { plasma ratio and 5-FU-related early } \\
\text { toxicity; relationship between 5-FU } \\
\text { concentration and toxicity; } \\
\text { IVS14+1G>A mutation screening. }\end{array}$ & & & $\begin{array}{c}D P Y D^{*} 2 \mathrm{~A} / \mathrm{UH}_{2} / \mathrm{U} \text { ratio in plasma } \\
\text { 5-FU clearance by HPLC-UV/ ADR } \\
\text { reported until the second cycle of } \\
\text { treatment. }\end{array}$ \\
\hline Deenen et al. (2011) [23] & 568 & $\begin{array}{l}\text { Relationships between SNPs and } \\
\text { toxicity, SNPs and dose } \\
\text { modification of capecitabine, DPYD } \\
\text { haplotypes and toxicity, DPYD } \\
\text { SNPs and haplotypes and survival. }\end{array}$ & $\begin{array}{l}D P Y D^{*} 2 \mathrm{~A}, \mathrm{c} .2846 \mathrm{~A}>\mathrm{T} \text { and } \\
\text { c.1236G }>\mathrm{A}[\text { HapB3]/ ADR } \\
\text { reported until the second } \\
\text { cycle of treatment. }\end{array}$ & & \\
\hline Deenen et al. (2016) [24] & 2038 & $\begin{array}{c}\text { Feasibility, safety and cost of } \\
D P Y D^{*} 2 \mathrm{~A} \text { genotype-guided dosing. }\end{array}$ & $\begin{array}{l}D P Y D^{*} 2 \mathrm{~A} / \mathrm{ADR} \text { reported } \\
\text { until the sixth cycle of } \\
\text { treatment. }\end{array}$ & & \\
\hline
\end{tabular}


Table 3. Cont.

\begin{tabular}{|c|c|c|c|c|c|}
\hline $\begin{array}{l}\text { First Author's Name } \\
\text { (Published Year) }\end{array}$ & $\begin{array}{l}\text { Enrolled } \\
\text { Patients (n) }\end{array}$ & Outcomes & $\begin{array}{l}\text { DPYD-PGx/Clinical } \\
\text { Monitoring }\end{array}$ & $\begin{array}{l}\text { DPYD-PGx/ } \\
\text { Phenotyping }\end{array}$ & $\begin{array}{c}\text { DPYD-PGx/Phenotyping/Clinical } \\
\text { Monitoring }\end{array}$ \\
\hline Sistonen et al. (2014) [25] & 28 & $\begin{array}{l}\text { Relationship between } \mathrm{UH}_{2} / \mathrm{U} \\
\text { plasma ratio and } D P Y D \text { genetic } \\
\text { variation; plasma concentration of } \\
5-\mathrm{FU} \text { and corresponding AUC; } \\
\text { toxicity. }\end{array}$ & & & $\begin{array}{l}\text { c.234-123G }>\text { C, c.496A }>\mathrm{G}, \\
\text { c.775A }>\mathrm{G}, \mathrm{c} .1129-5923 \mathrm{C}>\mathrm{G} \text { [Hap } \\
\text { B3], DPYD*13, DPYD*2A and } \\
\text { c.2846A }>\mathrm{T} / \mathrm{UH}_{2} / \mathrm{U} \text { ratio in plasma- } \\
\text { 5-FU clearance by LC-MS/MS/ ADR } \\
\text { reported until the second cycle of } \\
\text { treatment. }\end{array}$ \\
\hline Lee et al.(2014) [26] & 2886 & $\begin{array}{l}\text { Relationship between DPYD } \\
\text { variants and toxicity. }\end{array}$ & $\begin{array}{l}\text { DPYD*2A, DPYD*13, } \\
\text { c. } 2846 \mathrm{~A}>\mathrm{T} / \mathrm{ADR} \text { until the } \\
\text { twelfth cycle of treatment. }\end{array}$ & & \\
\hline Gentile et al. (2015) [27] & 156 & $\begin{array}{l}\text { Correlation between degradation } \\
\text { rate of 5-FU with detected SNPs. }\end{array}$ & & $\begin{array}{c}D P Y D^{*} 2 \mathrm{~A} \\
D P Y D^{*} 13 \\
\text { c.2846A }>\mathrm{T} / 5-\mathrm{FUDR} \\
\text { assay in PBMC by } \\
\text { HPLC-MS/MS }\end{array}$ & \\
\hline Joerger et al. (2015) [28] & 140 & $\begin{array}{l}\text { Quantitative effect of } 44 \text { gene } \\
\text { polymorphism in } 16 \text { drug pathway } \\
\text { associated genes on progression } \\
\text { free survival (PFS), on } \\
\text { chemotherapy toxicity, on objective } \\
\text { response rate (ORR), on overall } \\
\text { survival (OS). }\end{array}$ & & & $\begin{array}{c}D P Y D^{*} 13, D P Y D^{*} 2 \mathrm{~A}, \mathrm{c} .2846 \mathrm{~A}>\mathrm{T}, \\
D P Y D^{* 9 \mathrm{~A}}, \mathrm{c} .1896 \mathrm{~T}>\mathrm{C} / 5-\mathrm{FU} \\
\text { clearance by AAS and HPLC/ADR } \\
\text { until disease progression. }\end{array}$ \\
\hline Lunenburg et al. (2016) [29] & 275 & $\begin{array}{l}\text { Evaluation of requests of } \\
\text { prospective DPYD screening and } \\
\text { results with a dose } \\
\text { recommendation; estimation of the } \\
\text { follow up of the dose } \\
\text { recommendations. }\end{array}$ & $\begin{array}{c}D P Y D^{*} 2 \mathrm{~A}, D P Y D^{*} 13 \\
\text { c. } 2846 \mathrm{~A}>\mathrm{T}, \mathrm{c} .1236 \mathrm{G}>\mathrm{A} \\
{[\mathrm{HapB} 3] / \mathrm{ADR} \text { reported }} \\
\text { until the second cycle of } \\
\text { treatment. }\end{array}$ & & \\
\hline
\end{tabular}


Table 3. Cont.

\begin{tabular}{|c|c|c|c|c|c|}
\hline $\begin{array}{l}\text { First Author's Name } \\
\text { (Published Year) }\end{array}$ & $\begin{array}{l}\text { Enrolled } \\
\text { Patients (n) }\end{array}$ & Outcomes & $\begin{array}{l}\text { DPYD-PGx/Clinical } \\
\text { Monitoring }\end{array}$ & $\begin{array}{l}\text { DPYD-PGx/ } \\
\text { Phenotyping }\end{array}$ & $\begin{array}{c}\text { DPYD-PGx/Phenotyping/Clinical } \\
\text { Monitoring }\end{array}$ \\
\hline Galarza et al. (2016) [30] & 60 & $\begin{array}{l}\text { Estimation of the use of plasma and } \\
\text { saliva; Uracil to } \mathrm{UH}_{2} \text { metabolic } \\
\text { ratio and DPYD genotyping. }\end{array}$ & & & $\begin{array}{c}D P Y D * 2 \mathrm{~A}, * 13, \mathrm{c} .557 \mathrm{~A}>\mathrm{G}, \mathrm{DPYD} \\
* 7 / \mathrm{UH}_{2} / \mathrm{U} \text { ratio in plasma/ ADR } \\
\text { reported until the third cycle of } \\
\text { treatment. }\end{array}$ \\
\hline Milano et al. (2016) [31] & 243 & $\begin{array}{l}\text { Sequencing of } D P Y D \text { exome and } \\
\text { frequence of G3, G4 toxicity over } \\
\text { cycle 1-2. }\end{array}$ & $\begin{array}{l}D P Y D^{*} 2 \mathrm{~A}, D P Y D^{*} 13, \\
\text { c. } 2846 \mathrm{~A}>\mathrm{T}, \mathrm{c} .1774 \mathrm{C}>\mathrm{T}, \\
\text { c. } 1475 \mathrm{C}>\mathrm{T}, \mathrm{D} 342 \mathrm{G} / \mathrm{ADR} \\
\text { reported until the second } \\
\text { cycle of treatment. }\end{array}$ & & \\
\hline $\begin{array}{l}\text { Boisdron-Celle et al.(2017) } \\
\text { [32] }\end{array}$ & 85 & $\begin{array}{l}\text { UGT1A1 and DPYD genotyping; } \\
\mathrm{UH}_{2} / \mathrm{U} \text { ratio; follow up of efficacy } \\
\text { and tolerance. }\end{array}$ & & & $\begin{array}{c}D P Y D^{*} 2 \mathrm{~A}, D P Y D^{*} 13, \mathrm{c} .2846 \mathrm{~A}>\mathrm{T} \\
D P Y D^{*} 7 / \mathrm{UH}_{2} / \mathrm{U} \text { ratio in } \\
\text { plasma/ADR every two weeks until } \\
\text { three months. }\end{array}$ \\
\hline $\begin{array}{l}\text { Etienne-Grimaldi et } \\
\text { al.(2017) [33] }\end{array}$ & 243 & $\begin{array}{l}D P Y D \text { sequencing; relationship } \\
\text { between toxicity and } D P Y D \\
\text { variants; } D P D \text { phenotyping. }\end{array}$ & & & $\begin{array}{l}D P Y D^{*} 2 \mathrm{~A}, D P Y D^{*} 13, \mathrm{c} .2846 \mathrm{~A}>\mathrm{T} / \\
\mathrm{UH}_{2} / \mathrm{U} \text { ratio in plasma/ } \mathrm{ADR} \\
\text { reported until the second cycle of } \\
\text { treatment. }\end{array}$ \\
\hline Liu et al.(2017) [34] & 661 & $\begin{array}{l}\text { Relationship between } U G T 1 A 1 \text { and } \\
D P Y D \text { polymorphism and } \\
\text { incidence of severe neutropenia } \\
\text { and diarrhea; relationship between } \\
\text { UGT1A1 and DPYD variants and } \\
\text { objective response rate, disease } \\
\text { control rate, overall and } \\
\text { progression free survival. }\end{array}$ & $\begin{array}{l}D P Y D^{*} 5, \text { c. } 1896 \mathrm{~T}>\mathrm{C} \text {, and } \\
D P Y D^{*} 2 \mathrm{~A} / \mathrm{ADR} \text { reported } \\
\text { every two-three cycles or } \\
\text { whenever patient's } \\
\text { condition changed. }\end{array}$ & & \\
\hline
\end{tabular}


Table 3. Cont.

\begin{tabular}{|c|c|c|c|c|c|}
\hline $\begin{array}{l}\text { First Author's Name } \\
\text { (Published Year) }\end{array}$ & $\begin{array}{c}\text { Enrolled } \\
\text { Patients (n) }\end{array}$ & Outcomes & $\begin{array}{l}\text { DPYD-PGx/Clinical } \\
\text { Monitoring }\end{array}$ & $\begin{array}{l}\text { DPYD-PGx/ } \\
\text { Phenotyping }\end{array}$ & $\begin{array}{c}\text { DPYD-PGx/Phenotyping/Clinical } \\
\text { Monitoring }\end{array}$ \\
\hline Henricks et al.(2018) [35] & 1181 & $\begin{array}{l}\text { Frequency of severe overall } \\
\text { FP-related toxicity; } \\
\text { pharmacokinetics of } \\
\text { fluoropyrimidines in } D P Y D \text { variant } \\
\text { allele carriers; } D P D \text { enzyme } \\
\text { activity; cost analysis on } \\
\text { individualised dosing by upfront } \\
D P Y D \text { genotyping. }\end{array}$ & & & $\begin{array}{c}\text { DPYD*2A, c.2846A }>\text { T, DPYD*13 } \\
\text { and c.1236G }>\text { A [Hap B3]/ } \mathrm{UH}_{2} / \mathrm{U} \\
\text { ratio in PBMC/PK data by } \\
\text { UHPLC-MS/MS/ADR until toxicity } \\
\text { resolution. }\end{array}$ \\
\hline Cremolini et al. (2018) [36] & 443 & $\begin{array}{l}\text { Relationship between } D P Y D \text { and } \\
\text { UGT1A1 genotyping and toxicity. }\end{array}$ & $\begin{array}{c}D P Y D^{*} 2 \mathrm{~A},{ }^{*} 13 \\
\text { c. } 2846 \mathrm{~A}>\mathrm{T} / \mathrm{ADR} \text { reported } \\
\text { until the fourth cycle of } \\
\text { treatment. }\end{array}$ & & \\
\hline Jacobs et al.(2019) [37] & 237 & $\begin{array}{l}\text { Pharmacokinetics of capecitabine } \\
\text { and 5-FU in DPYD variant allele } \\
\text { carriers. }\end{array}$ & & $\begin{array}{c}\text { DPYD*2A, } \\
\text { c.2846A }>\mathrm{T}, \\
\text { c.1236G }>\mathrm{A} \\
{[\text { HapB3]/5-FU }} \\
\text { clearance by LC } \\
\text { MS/MS. }\end{array}$ & \\
\hline Iachetta et al.(2019) [38] & 1827 & $\begin{array}{l}\text { Relationship between } D P Y D \text { and } \\
\text { toxicity. }\end{array}$ & $\begin{array}{l}D P Y D^{*} 13, D P Y D^{*} 2 \mathrm{~A}, \\
\text { c.2846A }>\mathrm{T}, D P Y D^{*} 6 / \mathrm{ADR} \\
\text { reported until the } \\
\text { eleventh cycle of } \\
\text { treatment. }\end{array}$ & & \\
\hline Kleinjan et al. (2019) [39] & 185 & DPYD genotyping and toxicity. & $\begin{array}{c}D P Y D^{*} 2 \mathrm{~A}, \mathrm{c} .2846 \mathrm{~A}>\mathrm{T} \\
D P Y D^{*} 13 \text { and c. } 1236 \mathrm{G}>\mathrm{A} \\
{[\mathrm{HapB} 3] / \mathrm{ADR} \text { reported }} \\
\text { until the second cycle of } \\
\text { treatment. }\end{array}$ & & \\
\hline
\end{tabular}


Table 3. Cont.

\begin{tabular}{|c|c|c|c|c|c|}
\hline $\begin{array}{l}\text { First Author's Name } \\
\text { (Published Year) }\end{array}$ & $\begin{array}{l}\text { Enrolled } \\
\text { Patients (n) }\end{array}$ & Outcomes & $\begin{array}{l}\text { DPYD-PGx/Clinical } \\
\text { Monitoring }\end{array}$ & $\begin{array}{l}\text { DPYD-PGx/ } \\
\text { Phenotyping }\end{array}$ & $\begin{array}{c}\text { DPYD-PGx/Phenotyping/Clinica } \\
\text { Monitoring }\end{array}$ \\
\hline Negarandeh et al.(2020) [40] & 88 & $\begin{array}{l}\text { Relationship between DPYD } \\
\text { genotyping and toxicity. }\end{array}$ & $\begin{array}{c}D P Y D^{*} 2 \mathrm{~A}, \mathrm{c} .2846 \mathrm{~A}>\mathrm{T} \\
D P Y D^{*} 6 / \mathrm{ADR} \text { reported } \\
\text { following } 227 \text { cycles for } 88 \\
\text { patients. }\end{array}$ & & \\
\hline Nicolas Pallet et al.(2020) [41] & 5886 & $\begin{array}{l}\text { Relationship between } D P Y D \\
\text { genotyping and }[\mathrm{U}] \text { and } \mathrm{UH}_{2} / \mathrm{U} \\
\text { ratio in plasma. }\end{array}$ & & $\begin{array}{c}D P Y D^{*} 2 \mathrm{~A}, \\
D P Y D^{*} 13, \\
\text { c. } 2846 \mathrm{~A}>\mathrm{T}, \\
\text { c.1236G }>\mathrm{A}[\mathrm{HapB} 3] / \\
{[\mathrm{U}] \text { and } \mathrm{UH}_{2} / \mathrm{U} \text { ratio }} \\
\text { in plasma. }\end{array}$ & \\
\hline
\end{tabular}




\section{Discussion}

Fluoropyrimidines (FP) are the most-prescribed antineoplastic drugs in the world and represent the mainstay therapy for colorectal cancer. Unfortunately, $10-30 \%$ of the treated patients suffer from severe FP-related ADR [1].

The association between four DPYD variants and FP toxicity is now widely recognised, and it is also largely accepted that the pretherapeutic guiding dosing model based on the DPYD-PGx is a valid and cost-effective approach to manage FP-based chemotherapy. As a matter of fact, FP are included among the drugs with a pharmacogenetic warning [5], and the CPIC and DPWG guidelines are now followed in several countries, including Italy.

However, DPYD-PGx is not yet routinely performed, and one of the aims of these consortia is to overcome the barriers preventing the implementation of the PGx into clinical practice. In March 2019, the Pharmacovigilance Risk Assessment Committee (PRAC) of the European Medicines Agency (EMA) recommended to perform DPYD-PGx before starting treatment with FP. As in the CPIC and DPWG guidelines, the PRAC stated that 5-FU, capecitabine or tegafur must be avoided in the presence of a complete DPD deficiency. In the case of a partial DPD deficit, a reduced starting dose of FP should be considered [42].The PRAC recommendation was transferred to the Committee for Medicinal Products for Human Use (CHMP), and, on 7 July 2020, the EMA Commission raised a final decision that the DPYD-PGx should be performed in naïve oncological patients prior to starting a treatment with FP [43].

A substantial percentage of patients with a DPYD variant associated with a deficit of DPD activity show grade $>2$ toxicity [9]. For instance, it has been estimated that $73 \%$ of the patients who are carriers of $D P Y D^{*} 2 A$ suffer from grade $\geq 3$ toxicity [24]. Therefore, the upfront DPYD-PGx has a crucial impact on the management of chemotherapy given that it may prevent $20-30 \%$ of life-threatening or lethal FP-related toxicity in Caucasian patients, revealing also a cost-effective approach [24,44].

In this regard, case 1 suffered from grade 3 neutropenia and grade 3 mucositis before the DPYD-PGx was required, which then revealed the presence of $D P Y D^{*} 2 A$ SNP. Notably, once the PGx results were obtained, the patient received $50 \%$ of the 5 -FU dosage, and at the fourth and following cycles, there was no evidence for severe ADR.

The importance of performing a pretherapeutic DPYD-PGx is confirmed by the history of two other patients who had experienced grade 3 toxicity, with a different timing, before the test was requested. One of them was identified as $D P Y D^{*} 2 A$ heterozygous and the other one as DPYD c.2846 heterozygous. It is possible to conclude that FP-related severe toxicity may occur anytime during the therapy. The $D P Y D^{*} 2 A$, which is a no-function variant, could be associated with a more premature ADR when compared with $D P Y D$ c.2846A $>T$ SNP, which is classified as reduced-function variant. In fact, the subject bearing the $D P Y D^{*} 2 A$ suffered from grade 3 vomit at the second cycle, while the other patient, who was the carrier of the DPYD c.2846, suffered from the same toxicity but at the eighth cycle of chemotherapy.

Notably, it has been estimated that a $30-50 \%$ of the patients treated with FP have no DPD deficit attributable to the four recommended DPYD SNPs, yet suffer from severe ADR [45]. In fact, several factors concur to determine the variability of responses to FP-based treatments. Among them, other polymorphisms in DPYD, and in other genes encoding enzymes involved in the pathway of the FP and, also, FP-associated drugs, may play an important role. In this regard, several studies have shown an association between the TYM-TSER 28-bp variant (in the gene encoding the FP molecular target) and FP-related toxicity $[12,46]$. Moreover, an increased risk of severe toxicity has been shown in patients carrying rs183205964 in the promoter enhancer region of TYMS [46].

Finding the relationship between FP and specific ADR can be very difficult also, because FP are often administered with both traditional and biologic antineoplastic agents, such as cetuximab and bevacizumab. These drugs, as well as oxaliplatin and irinotecan, can cause diarrhoea and myelosuppression [47-50] similar to FP, and, as already mentioned, there are several genetic variants that are associated to these ADR and others. 
The MTHFR is a critical enzyme involved in the synthesis of purine and thymidine and, in general, folate homeostasis. Two common SNPs (i.e., MTHFR-C677T and -A1298C), associated with a decrease of the MTHFR enzymatic activity, have been proposed as predictive factors of the response to cytotoxic agents, including FP, raltitrexed and methotrexate [51]. In addition, these two SNPs may exert a synergistic effect on the MTHFR activity [11]. A recent metanalysis failed to recognise the MTHFR polymorphisms (neither MTHFR-C677T nor -A1298C) as predicting factors for the response to FP-based treatment [52]. The data often contrast each other because of several reasons, including the type of cancer, dietary folate levels, therapy regimen and saturation level of the enzyme [51].

Oxaliplatin is mainly metabolised by glutathione-S-transferase P1 (GSTP1), and the SNP in this gene (i.e., GSTP1 A313G, Ile105val and rs1695) has been associated with severe ADR. Most of the evidence regards the occurrence of cumulative neuropathy associated with such a polymorphism [12,53], but the presence of at least one variant allele has been associated also with grade 3 or 4 gastrointestinal and haematological toxicity [54].

In a recent metanalysis, Lv et al. found an association between the GSTP1 rs1695 SNP and granulocytopenia induced by platinum derivatives [55]. Another metanalysis failed to demonstrate that this polymorphism can be considered a reliable predictive factor of oxaliplatin-related severe neurotoxicity [56]. At present, the data are inconclusive; therefore, only large, well-designed clinical trials will be able to clarify this issue.

The TYMS-TSER 28-bp tandem repeat is one of the more promising candidates as a genetic factor responsible for FP-related ADR. However, as reported in the last CPIC update, its clinical relevance is still debated [5].

Lecomte et al. found that patients who were carriers of the double-repeat allele (i.e., TYMS-TSER-2R) had more severe FP-associated ADR than the homozygous -3R/3R. In particular, the authors reported that patients bearing the $-2 R / 2 R$ genotype were 20 times more likely to suffer from severe toxicity compared with those who are carriers of the $-3 R / 3 R$ genotype. This could be related to a decreased TYMS mRNA expression in the normal tissue of subjects bearing a $2 \mathrm{R} / 2 \mathrm{R}$ genotype that may lead to increased thymidylate synthase (TS) inhibition by FP treatment [11]. These findings refer to the somatic variant, while the data regarding the same germline polymorphism, which is identifiable by means of a peripheral blood sample, are inconclusive. Obviously, if the germline variant could be considered a predictive parameter like the somatic ones, a less-invasive method would be available to individualise the FP-based treatment in naïve patients. Several recent studies have suggested that the TYMS TSER germline polymorphism may be useful to prevent toxicity [57], such as hand-foot syndrome and other ADR types, including haematological and gastrointestinal ones [58]. With regards to the clinical cases described in Table 1 , case 1 was homozygous TYMS TSER-2R/2R and case 2 and 3 were heterozygous $2 R / 3 R$.

Undoubtedly, a larger panel of genetic variants is needed. On the other hand, further studies should be performed to support the regulatory authorities to decide whether and which new polymorphisms should be added to the four recommended DPYD SNPs in the PGx guidelines. Researchers' efforts are addressed to find the best phenotyping methods to complement the DPYD-PGx. Among the different approaches proposed until now, the analysis of the 5-FU pharmacokinetic parameters was evaluated even before the DPYD-PGx introduction. In the eighties, in fact, a high individual variability of the plasmatic 5-FU clearance was demonstrated, and the existence of a correlation between the 5-FU levels and FP-related toxicity had already been highlighted [59].

Nowadays, it is possible to determine the 5-FU clearance using sophisticated techniques, such as HPLC coupled with tandem mass spectrometry (LC-MS/MS), which provides the precious opportunity to carry out TDM to adjust the therapy cycle-by-cycle where appropriate. Nonetheless, this approach is not always feasible in hospital settings and is unable to detect a DPD deficit prior to starting the treatment, thus preventing an early severe toxicity. Moreover, a 5-FU pharmacokinetic analysis aims at measuring the area under the curve (AUC) of the 5-FU plasma levels at the steady state (i.e., $2 \mathrm{~h}$ after the drug administration) and requires collecting multiple blood samples [14]. 
The CPIC and DPWG guidelines recommend to perform the DPYD-PGx and to treat the heterozygous patients with a dose reduction at the first cycle of chemotherapy and then titrate the dosage while performing a careful clinical monitoring and possibly TDM $[5,6]$.

An ideal management workflow should consent to optimise FP-based therapy before treatment using the least invasive method; therefore, the researchers' efforts have been addressed in this direction.

The measure of the plasmatic $\mathrm{UH} 2 / \mathrm{U}$ ratio has been proposed as a suitable approach, but its validity is brought up for discussion. Indeed, some studies have demonstrated that this parameter well-correlates with 5-FU clearance and FP-related toxicity [22], while others have suggested that it can be considered a valid predictive factor during 5-FU administration alone [25]. Notably, determining the UH2/U ratio in peripheral blood mononuclear cells (PBMCs) seems to be the best method, but, unfortunately, it is a time-consuming procedure and requires radiolabelled reagents and large volumes of blood $[20,35,60]$.

Importantly, it seems that only a low plasmatic UH2/U ratio is a good predictive factor. For instance, Gamelin et al. suggested that a value less than 1.8 really helps to identify the patients at higher risk of FP-related toxicity [61]. To this line, Kristensen et al. studied 24 patients treated with FP who experienced FP severe-related toxicity, finding that 21 out of 24 subjects had a UH2/U ratio $\leq 4$. They stated that the average $\mathrm{UH} 2 / \mathrm{U}$ ratio decreased with the toxicity grade and proposed the value of 4 as the cut-off value [22]. Other authors have fixed the cut-off value at 6 , specifying that the patients carrying one functional and one nonfunctional allele of DPYD (i.e., heterozygous) have a UH2/U ratio ranging from 1.5 to 6 , while those who are carriers of two nonfunctional alleles (i.e., homozygous) have a value close to 0 , corresponding to a complete DPD deficiency [62].

Besides the patients described in Table 1, we have measured the plasmatic UH2/U ratio in another eight subjects who are all heterozygous for DPYD*2A or DPYD c.2846A>T. We did not perform the pharmacokinetic analysis on these patients for several reasons (e.g., unavailability of the patients consents and changes of the therapy). It is important to underline that in six out of eight patients for whom a pretherapeutic DPYD-PGx was performed and the starting 5-FU dosage was halved, no severe toxicity was recorded (Table 2 ).

In the 11 patients we examined, the $\mathrm{UH} 2 / \mathrm{U}$ ratio ranged between 1.77 and 7.38.

The fluctuation of the UH2/U ratio values as a predictive factor could reflect the variability of the DPD deficit that may range from $30 \%$ to $70 \%$ in the heterozygous patients. Nonetheless, the plasmatic $\mathrm{UH} 2 / \mathrm{U}$ ratio could contribute to identifying, before beginning treatment, the subjects who are at-risk of severe or life-threatening ADR. Case 3 (reported in Table 1) exemplifies the complexity of the management of FP-based therapy. In fact, he had a very low (i.e., 1.7) plasmatic UH2/U ratio and continued suffering from severe toxicity despite the reduction of the 5-FU dosage. It is mandatory to bear in mind that this ratio remains a surrogate marker of DPD activity, and even if it was a more sensitive and specific parameter, several other variables may influence both the efficacy and tolerability of FP-based chemotherapy.

This is the reason why a combined genotyping/phenotyping approach, together with careful clinical monitoring, is the best way to personalise and optimise the therapy. Several studies have used this kind of approach, suggesting that phenotyping analyses, especially those based on the plasmatic 5-FU clearance and/or UH2/U ratio measurement, could successfully complement the DPYD-PGx in predicting FP-related toxicity. This is clearly shown by our systematic literature search (Figure 1 and Table 3).

As shown in Table 3, eight studies have combined DPYD-PGx with phenotyping methods and clinical monitoring, but only two out of eight have provided satisfactory clinical monitoring [28,35]. Indeed, to perform daily careful, clinical monitoring during all patients' treatment cycles is very arduous. In fact, among these studies, three out of eight reported ADR only for two cycles [22,25,33], one out of eight monitored the toxicity until the third cycle [30] and two out of eight made clinical monitoring for two-to-three months [20,32]. 
Moreover, as shown in Table 3, three studies have performed a combined DPYD-PGx/phenotyping $[27,37,41]$ approach, and eleven carried out the DPYD-PGx together with clinical monitoring. However, among these, only 2/11 genotyped all the four DPYD SNPs recommended in the CPIC and DPWG guidelines [29,39]; the other studies performed at least one of such SNPs, together with other DPYD genetic variants [21-40].

The main limitations of the studies performed until now are the lack of clinical monitoring throughout the entire course of chemotherapy and the scarce sample size. Moreover, the missing of the screening of one or more of the four DPYD-SNPs now recommended and the heterogeneity in the choice of other polymorphisms potentially useful to implement genotyping do not allow reaching conclusive results.

\section{Conclusions}

The pretherapeutic DPYD-PGx represents an essential approach to personalise FP-based chemotherapy, minimising the risk of severe and life-threatening toxicity. This is confirmed by both the clinical cases here described and the literature data.

Nowadays, the regulatory agencies recommend carrying out the DPYD-PGx, including four DPYD polymorphisms (i.e., rs3918290, rs55886062, rs67376798 and rs75017182, HapB3) in patients who need to be treated with FP.

Despite that these DPYD variants are strongly associated with treatment toxicity, other genetic and nongenetic factors concur to determine the variable response to FP-based chemotherapy.

Initiating the FP with a reduced dosage is not a suitable option, because DPD deficits may range from $30 \%$ to $70 \%$ in the heterozygous patients who would experience a dangerous period of undertreatment.

A pretherapeutic DPYD-PGx offers the possibility to avoid early ADR. Nonetheless, severe and even fatal FP-related toxicity may happen anytime during the therapy also in subjects having no DPD deficit attributable to the four recommended DPYD SNPs.

On the other hand, measuring the plasmatic 5-FU clearance-currently, the best method to perform TDM-does not permit to diagnose a possible DPD deficit prior to starting the treatment.

Therefore, because both genetic and phenotypic tests show advantages and disadvantages, a combined genotyping/phenotyping approach, together with careful and continuous clinical monitoring, is the best diagnostic method to optimise the therapy with FP (Figure 2).

An accurate genotypic/phenotypic characterisation of each patient is essential not only to prevent severe toxicity associated with the cytotoxic agents but, also, to determine patients' benefit-risk profiles to begin early the best therapeutic approach. This is of particular interest considering the current possibility to treat certain patients with anticancer agents, such as immune checkpoint inhibitors, that are changing the cancer therapeutic paradigm. 


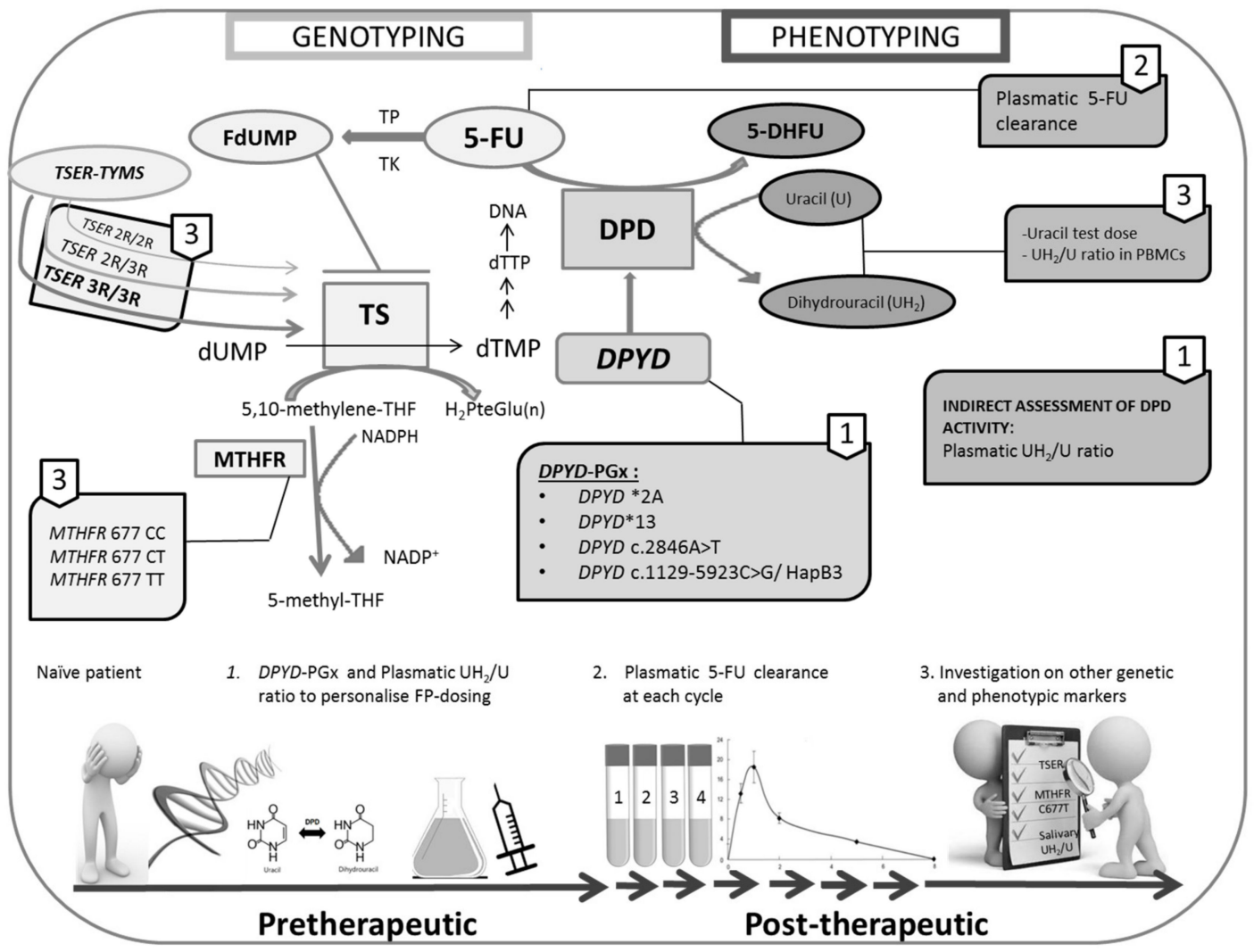

Figure 2. This figure illustrates the main enzymatic reactions involved in the fluoropyrimidines (FP) pathway. The importance to perform, together with careful clinical monitoring, a genotyping/phenotyping combined approach is shown by using panels and arrows. The four recommended DPYD-SNPs, including in the DPYD-PGx, are listed, together with the other polymorphisms proposed as potential predictive factors of FP-related toxicity. Phenotyping methods (e.g., UH2/U ratio measured in plasma or PBMCs), which potential in predicting FP safety are currently under evaluation, are also described. An ideal flowchart to manage patients eligible for FP-based therapy is shown at the bottom of the figure. DPYD-PGx and the plasmatic UH2/U ratio have to perform one time (continuous line), while the plasmatic 5-FU clearance is throughout the entire course of the therapy (dotted line). The numbers located on the panels are the same reported in the flowchart in order to underline which genotyping and phenotyping markers may be used together to optimise the diagnosis and management of patients. Abbreviations: DPD, dihydropyrimidine dehydrogenase; DPYD-PGx, DPYD-pharmacogenomics; 5-FU, fluorouracil; DHFU, 5-fluoro-dihydrouracil; TP, thymidine phosphorylase; TK, thymidine kinase; FdUMP, 5-fluorodeoxyuridine monophosphate; TS, thymidylate synthase; dUMP, deoxyuridine monophosphate; dTMP, deoxythymidine monophosphate; dTTP, deoxythymidine triphosphate; 5,10-methylene-THF, 5,10-methylene-tetrahydrofolate; H2PteGlu(n), dihydrofolic acid; MTHFR, methylene-tetrahydrofolate reductase; 5-methyl-THF, 5,10-methyl-tetrahydrofolate; NADPH, nicotinamide adenine dinucleotide phosphate and TYMS-TSER, thymidylate synthase-thymidylate synthase enhancer region.

Author Contributions: Conceptualisation, A.F., V.C., F.S. and S.P.; methodology, V.M., E.D.B., F.D.P., F.I., M.T., B.C. and A.C.; validation, V.C., B.S. and F.C.; investigation, V.C., V.M., E.D.B. and A.F.; resources, A.F. and V.C.; data curation, E.D.B., B.S., V.C., F.I. and T.I.; writing-original draft preparation, V.C., E.D.B., V.M., V.I. and M.T.; writing-review and editing, V.C., A.F., F.S., V.I. and F.D.P.; supervision, V.C. and A.F.; project administration, V.C., V.M. and A.F. and funding acquisition, A.F. and V.C. All authors have read and agreed to the published version of the manuscript.

Funding: Italian Medicines Agency (AIFA) AVPM/17806/A (Rome, Italy) and Reti Oncologiche, Campania Region (2018) fund to A.F. at University Hospital of Salerno (Salerno, Italy) and University ORSA175354 fund (University of Salerno, Italy) to V.C. 
Acknowledgments: We thank the native English-speaker Jan Festa, who revised the manuscript.

Conflicts of Interest: The authors declare no conflict of interest.

\section{Abbreviations}

$\begin{array}{ll}\text { FP } & \text { Fluoropyrimidines } \\ \text { DPD } & \text { Dihydropyrimidine Dehydrogenase } \\ \text { DPYD-PGx } & \text { DPYD-Pharmacogenomics } \\ \text { PCR } & \text { Polymerase Chain Reaction } \\ \text { 5-FU } & \text { 5-Fluorouracil } \\ \text { ADR } & \text { Adverse Drug Reaction } \\ \text { HFS } & \text { Hand-Foot Syndrome } \\ \text { SNPs } & \text { Single-Nucleotide Polymorphisms } \\ \text { CPIC } & \text { The Clinical Pharmacogenetics Implementation Consortium } \\ \text { DPWG } & \text { Dutch Pharmacogenetics Working Group } \\ \text { DPYD-AS } & \text { DPYD-Activity Score } \\ \text { TDM } & \text { Therapeutic Drug Monitoring } \\ \text { MTHFR } & \text { Methylene-Tetrahydrofolate Reductase } \\ \text { TYMS-TSER } & \text { Thymidylate Synthase-Thymidylate Synthase Enhancer Region } \\ \text { GSTP1 } & \text { Glutathione S-Trasferase-p1 } \\ \text { UH2/U ratio } & \text { Dihydrouracil/Uracil Ratio } \\ \text { CTC-AE } & \text { Common Terminology Criteria for Adverse Events } \\ \text { RECIST } & \text { Response Evaluation Criteria in Solid Tumours } \\ \text { HPLC } & \text { High-Performance Liquid Chromatography } \\ \text { UHPLC-MS/MS } & \text { Ultra-High-Performance Liquid Chromatography-Tandem Mass Spectrometry } \\ \text { MeSH } & \text { Medical Subject Heading } \\ \text { PRISMA } & \text { Preferred Reporting Items for Systematic reviews and Meta-Analyses } \\ \text { FOLFOX } & \text { 5-FU, Leucovorin and Oxaliplatin } \\ \text { CT scan } & \text { Computed Tomography Scan } \\ \text { FOLFIRI } & \text { 5-FU, Leucovorin and Irinotecan } \\ \text { PRAC } & \text { Pharmacovigilance Risk Assessment Committee } \\ \text { EMA } & \text { European Medicines Agency } \\ \text { CHMP } & \text { Committee for Medicinal Products for Human Use } \\ \text { AUC } & \text { Area Under the Curve } \\ \text { LC-MS/MS } & \text { Liquid Chromatography-Tandem Mass Spectrometry } \\ \text { PBMCs } & \text { Peripheral Blood Mononuclear Cells } \\ & \end{array}$

\section{References}

1. Longley, D.B.; Harkin, D.P.; Johnston, P.G. 5-Fluorouracil: Mechanisms of Action and Clinical Strategies. Nat. Rev. Cancer 2003, 3, 330-338. [CrossRef] [PubMed]

2. Venook, A.P.; Niedzwiecki, D.; Lenz, H.-J.; Innocenti, F.; Fruth, B.; Meyerhardt, J.A.; Schrag, D.; Greene, C.; O'Neil, B.H.; Atkins, J.N.; et al. Effect of First-Line Chemotherapy Combined with Cetuximab or Bevacizumab on Overall Survival in Patients With KRAS Wild-Type Advanced or Metastatic Colorectal Cancer: A Randomized Clinical Trial. JAMA 2017, 317, 2392-2401. [CrossRef] [PubMed]

3. Hoff, P.M.; Ansari, R.; Batist, G.; Cox, J.; Kocha, W.; Kuperminc, M.; Maroun, J.; Walde, D.; Weaver, C.; Harrison, E.; et al. Comparison of Oral Capecitabine versus Intravenous Fluorouracil plus Leucovorin as First-Line Treatment in 605 Patients with Metastatic Colorectal Cancer: Results of a Randomized Phase III Study. J. Clin. Oncol. Off. J. Am. Soc. Clin. Oncol. 2001, 19, 2282-2292. [CrossRef] [PubMed]

4. Van Kuilenburg, A.B.P.; Dobritzsch, D.; Meijer, J.; Meinsma, R.; Benoist, J.-F.; Assmann, B.; Schubert, S.; Hoffmann, G.F.; Duran, M.; de Vries, M.C.; et al. Dihydropyrimidinase Deficiency: Phenotype, Genotype and Structural Consequences in 17 Patients. Biochim. Biophys. Acta 2010, 1802, 639-648. [CrossRef] 
5. Amstutz, U.; Henricks, L.M.; Offer, S.M.; Barbarino, J.; Schellens, J.H.M.; Swen, J.J.; Klein, T.E.; McLeod, H.L.; Caudle, K.E.; Diasio, R.B.; et al. Clinical Pharmacogenetics Implementation Consortium (CPIC) Guideline for Dihydropyrimidine Dehydrogenase Genotype and Fluoropyrimidine Dosing: 2017 Update. Clin. Pharmacol. Ther. 2018, 103, 210-216. [CrossRef]

6. Lunenburg, C.A.T.C.; van der Wouden, C.H.; Nijenhuis, M.; Crommentuijn-van Rhenen, M.H.; de Boer-Veger, N.J.; Buunk, A.M.; Houwink, E.J.F.; Mulder, H.; Rongen, G.A.; van Schaik, R.H.N.; et al. Dutch Pharmacogenetics Working Group (DPWG) Guideline for the Gene-Drug Interaction of DPYD and Fluoropyrimidines. Eur. J. Hum. Genet. 2020, 28, 508-517. [CrossRef]

7. Del Re, M.; Cinieri, S.; Michelucci, A.; Salvadori, S.; Loupakis, F.; Schirripa, M.; Cremolini, C.; Crucitta, S.; Barbara, C.; Di Leo, A.; et al. DPYD*2A and c.2846A>T: A Comprehensive Analysis in 1254 Patients. Pharm. J. 2019, 19, 556-563. [CrossRef]

8. Van Kuilenburg, A.B.P.; Meijer, J.; Mauer, D.; Dobritzsch, D.; Meinsma, R.; Los, M.; Knegt, L.C.; Zoetekouw, L.; Jansen, R.L.H.; Dezentjé, V.; et al. Severe Fluoropyrimidine Toxicity Due to Novel and Rare DPYD Missense Mutations, Deletion and Genomic Amplification Affecting DPD Activity and MRNA Splicing. Biochim. Biophys. Acta Mol. Basis Dis. 2017, 1863, 721-730. [CrossRef]

9. Coenen, M.J.H.; Paulussen, A.D.C.; Breuer, M.; Lindhout, M.; Tserpelis, D.C.J.; Steyls, A.; Bierau, J.; van den Bosch, B.J.C. Evolution of Dihydropyrimidine Dehydrogenase Diagnostic Testing in a Single Center during an 8-Year Period of Time. Curr. Ther. Res. Clin. Exp. 2019, 90, 1-7. [CrossRef]

10. Ulvik, A.; Ueland, P.M.; Fredriksen, A.; Meyer, K.; Vollset, S.E.; Hoff, G.; Schneede, J. Functional Inference of the Methylenetetrahydrofolate Reductase 677C > T and 1298A > C Polymorphisms from a Large-Scale Epidemiological Study. Hum. Genet. 2007, 121, 57-64. [CrossRef]

11. Lecomte, T.; Ferraz, J.-M.; Zinzindohoué, F.; Loriot, M.-A.; Tregouet, D.-A.; Landi, B.; Berger, A.; Cugnenc, P.-H.; Jian, R.; Beaune, P.; et al. Thymidylate Synthase Gene Polymorphism Predicts Toxicity in Colorectal Cancer Patients Receiving 5-Fluorouracil-Based Chemotherapy. Clin. Cancer Res. Off. J. Am. Assoc. Cancer Res. 2004, 10, 5880-5888. [CrossRef] [PubMed]

12. McLeod, H.L.; Sargent, D.J.; Marsh, S.; Green, E.M.; King, C.R.; Fuchs, C.S.; Ramanathan, R.K.; Williamson, S.K.; Findlay, B.P.; Thibodeau, S.N.; et al. Pharmacogenetic Predictors of Adverse Events and Response to Chemotherapy in Metastatic Colorectal Cancer: Results from North American Gastrointestinal Intergroup Trial N9741. J. Clin. Oncol. Off. J. Am. Soc. Clin. Oncol. 2010, 28, 3227-3233. [CrossRef] [PubMed]

13. Boisdron-Celle, M.; Remaud, G.; Traore, S.; Poirier, A.L.; Gamelin, L.; Morel, A.; Gamelin, E. 5-Fluorouracil-Related Severe Toxicity: A Comparison of Different Methods for the Pretherapeutic Detection of Dihydropyrimidine Dehydrogenase Deficiency. Cancer Lett. 2007, 249, 271-282. [CrossRef] [PubMed]

14. Van Staveren, M.C.; Jan Guchelaar, H.; Van Kuilenburg, A.B.P.; Gelderblom, H.; Maring, J.G. Evaluation of Predictive Tests for Screening for Dihydropyrimidine Dehydrogenase Deficiency. Pharm. J. 2013, 13, 389-395. [CrossRef]

15. National Cancer Institute Home Page. Available online: https://ctep.cancer.gov/protocoldevelopment/ electronic_applications/docs/CTCAE_v5_Quick_Reference_5x7.pdf (accessed on 11 July 2020).

16. Eisenhauer, E.A.; Therasse, P.; Bogaerts, J.; Schwartz, L.H.; Sargent, D.; Ford, R.; Dancey, J.; Arbuck, S.; Gwyther, S.; Mooney, M.; et al. New Response Evaluation Criteria in Solid Tumours: Revised RECIST Guideline (Version 1.1). Eur. J. Cancer 2009, 45, 228-247. [CrossRef]

17. Svobaite, R.; Solassol, I.; Pinguet, F.; Ivanauskas, L.; Brès, J.; Bressolle, F.M.M. HPLC with UV or Mass Spectrometric Detection for Quantifying Endogenous Uracil and Dihydrouracil in Human Plasma. Clin. Chem. 2008, 54, 1463-1472. [CrossRef]

18. Büchel, B.; Rhyn, P.; Schürch, S.; Bühr, C.; Amstutz, U.; Largiadèr, C.R. LC-MS/MS Method for Simultaneous Analysis of Uracil, 5,6-Dihydrouracil, 5-Fluorouracil and 5-Fluoro-5,6-Dihydrouracil in Human Plasma for Therapeutic Drug Monitoring and Toxicity Prediction in Cancer Patients. Biomed. Chromatogr. 2013, 27, 7-16. [CrossRef]

19. Shamseer, L.; Moher, D.; Clarke, M.; Ghersi, D.; Liberati, A.; Petticrew, M.; Shekelle, P.; Stewart, L.A. Preferred Reporting Items for Systematic Review and Meta-Analysis Protocols (PRISMA-P) 2015: Elaboration and Explanation. BMJ 2015, 350, g7647. [CrossRef] 
20. Van Kuilenburg, A.B.; Haasjes, J.; Richel, D.J.; Zoetekouw, L.; Van Lenthe, H.; De Abreu, R.A.; Maring, J.G.; Vreken, P.; van Gennip, A.H. Clinical Implications of Dihydropyrimidine Dehydrogenase (DPD) Deficiency in Patients with Severe 5-Fluorouracil-Associated Toxicity: Identification of New Mutations in the DPD Gene. Clin. Cancer Res. Off. J. Am. Assoc. Cancer Res. 2000, 6, 4705-4712.

21. Schwab, M.; Zanger, U.M.; Marx, C.; Schaeffeler, E.; Klein, K.; Dippon, J.; Kerb, R.; Blievernicht, J.; Fischer, J.; Hofmann, U.; et al. Role of Genetic and Nongenetic Factors for Fluorouracil Treatment-Related Severe Toxicity: A Prospective Clinical Trial by the German 5-FU Toxicity Study Group. J. Clin. Oncol. 2008, 26, 2131-2138. [CrossRef]

22. Kristensen, M.H.; Pedersen, P.; Mejer, J. The Value of Dihydrouracil/Uracil Plasma Ratios in Predicting 5-Fluorouracilrelated Toxicity in Colorectal Cancer Patients. J. Int. Med. Res. 2010, 38, 1313-1323. [CrossRef]

23. Deenen, M.J.; Tol, J.; Burylo, A.M.; Doodeman, V.D.; De Boer, A.; Vincent, A.; Guchelaar, H.-J.; Smits, P.H.M.; Beijnen, J.H.; Punt, C.J.A.; et al. Relationship between Single Nucleotide Polymorphisms and Haplotypes in DPYD and Toxicity and Efficacy of Capecitabine in Advanced Colorectal Cancer. Clin. Cancer Res. 2011, 17, 3455-3468. [CrossRef] [PubMed]

24. Deenen, M.J.; Meulendijks, D.; Cats, A.; Sechterberger, M.K.; Severens, J.L.; Boot, H.; Smits, P.H.; Rosing, H.; Mandigers, C.M.P.W.; Soesan, M.; et al. Upfront Genotyping of $D P Y D^{*} 2 A$ to Individualize Fluoropyrimidine Therapy: A Safety and Cost Analysis. J. Clin. Oncol. 2016, 34, 227-234. [CrossRef] [PubMed]

25. Sistonen, J.; Büchel, B.; Froehlich, T.K.; Kummer, D.; Fontana, S.; Joerger, M.; Van Kuilenburg, A.B.P.; Largiadèr, C.R. Predicting 5-Fluorouracil Toxicity: DPD Genotype and 5,6-Dihydrouracil:Uracil Ratio. Pharmacogenomics 2014, 15, 1653-1666. [CrossRef] [PubMed]

26. Lee, A.M.; Shi, Q.; Pavey, E.; Alberts, S.R.; Sargent, D.J.; Sinicrope, F.A.; Berenberg, J.L.; Goldberg, R.M.; Diasio, R.B. DPYD variants as predictors of 5-fluorouracil toxicity in adjuvant colon cancer treatment (NCCTG N0147). J. Natl. Cancer Inst. 2014, 106. [CrossRef]

27. Gentile, G.; Botticelli, A.; Lionetto, L.; Mazzuca, F.; Simmaco, M.; Marchetti, P.; Borro, M. Genotype-Phenotype Correlations in 5-Fluorouracil Metabolism: A Candidate DPYD Haplotype to Improve Toxicity Prediction. Pharm. J. 2016, 16, 320-325. [CrossRef] [PubMed]

28. Joerger, M.; Huitema, A.D.R.; Boot, H.; Cats, A.; Doodeman, V.D.; Smits, P.H.M.; Vainchtein, L.; Rosing, H.; Meijerman, I.; Zueger, M.; et al. Germline TYMS Genotype Is Highly Predictive in Patients with Metastatic Gastrointestinal Malignancies Receiving Capecitabine-Based Chemotherapy. Cancer Chemother. Pharmacol. 2015, 75, 763-772. [CrossRef]

29. Lunenburg, C.A.T.C.; Van Staveren, M.C.; Gelderblom, H.; Guchelaar, H.-J.; Swen, J.J. Evaluation of Clinical Implementation of Prospective DPYD Genotyping in 5-Fluorouracil- or Capecitabine-Treated Patients. Pharmacogenomics 2016, 17, 721-729. [CrossRef]

30. Galarza, A.F.A.; Linden, R.; Antunes, M.V.; Hahn, R.Z.; Raymundo, S.; da Silva, A.C.C.; Staggemeier, R.; Spilki, F.R.; Schwartsmann, G. Endogenous Plasma and Salivary Uracil to Dihydrouracil Ratios and DPYD Genotyping as Predictors of Severe Fluoropyrimidine Toxicity in Patients with Gastrointestinal Malignancies. Clin. Biochem. 2016, 49, 1221-1226. [CrossRef]

31. Milano, G. Highlight on DPYD Gene Polymorphisms and Treatment by Capecitabine*. Scand. J. Clin. Lab. Invest. 2016, 76, S30-S33. [CrossRef]

32. Boisdron-Celle, M.; Metges, J.P.; Capitain, O.; Adenis, A.; Raoul, J.L.; Lecomte, T.; Lam, Y.H.; Faroux, R.; Masliah, C.; Poirier, A.L.; et al. A Multicenter Phase II Study of Personalized FOLFIRI-Cetuximab for Safe Dose Intensification. Semin. Oncol. 2017, 44, 24-33. [CrossRef] [PubMed]

33. Etienne-Grimaldi, M.-C.; Boyer, J.-C.; Beroud, C.; Mbatchi, L.; Van Kuilenburg, A.; Bobin-Dubigeon, C.; Thomas, F.; Chatelut, E.; Merlin, J.-L.; Pinguet, F.; et al. New Advances in DPYD Genotype and Risk of Severe Toxicity under Capecitabine. PLoS ONE 2017, 12. [CrossRef] [PubMed]

34. Liu, D.; Li, J.; Gao, J.; Li, Y.; Yang, R.; Shen, L. Examination of Multiple UGT1A and DPYD Polymorphisms Has Limited Ability to Predict the Toxicity and Efficacy of Metastatic Colorectal Cancer Treated with Irinotecan-Based Chemotherapy: A Retrospective Analysis. BMC Cancer 2017, 17. [CrossRef] [PubMed]

35. Henricks, L.M.; Lunenburg, C.A.T.C.; de Man, F.M.; Meulendijks, D.; Frederix, G.W.J.; Kienhuis, E.; Creemers, G.-J.; Baars, A.; Dezentjé, V.O.; Imholz, A.L.T.; et al. DPYD Genotype-Guided Dose Individualisation of Fluoropyrimidine Therapy in Patients with Cancer: A Prospective Safety Analysis. Lancet Oncol. 2018, 19, 1459-1467. [CrossRef] 
36. Cremolini, C.; Del Re, M.; Antoniotti, C.; Lonardi, S.; Bergamo, F.; Loupakis, F.; Borelli, B.; Marmorino, F.; Citi, V.; Cortesi, E.; et al. DPYD and UGT1A1 Genotyping to Predict Adverse Events during First-Line FOLFIRI or FOLFOXIRI plus Bevacizumab in Metastatic Colorectal Cancer. Oncotarget 2018, 9, 7859-7866. [CrossRef]

37. Jacobs, B.A.W.; Deenen, M.J.; Joerger, M.; Rosing, H.; de Vries, N.; Meulendijks, D.; Cats, A.; Beijnen, J.H.; Schellens, J.H.M.; Huitema, A.D.R. Pharmacokinetics of Capecitabine and Four Metabolites in a Heterogeneous Population of Cancer Patients: A Comprehensive Analysis. CPT Pharmacomet. Syst. Pharmacol. 2019, 8, 940-950. [CrossRef]

38. Iachetta, F.; Bonelli, C.; Romagnani, A.; Zamponi, R.; Tofani, L.; Farnetti, E.; Nicoli, D.; Damato, A.; Banzi, M.; Casali, B.; et al. The Clinical Relevance of Multiple DPYD Polymorphisms on Patients Candidate for Fluoropyrimidine Based-Chemotherapy. An Italian Case-Control Study. Br. J. Cancer 2019, 120, 834-839. [CrossRef]

39. Kleinjan, J.P.; Brinkman, I.; Bakema, R.; Van Zanden, J.J.; Van Rooijen, J.M. Tolerance-Based Capecitabine Dose Escalation after DPYD Genotype-Guided Dosing in Heterozygote DPYD Variant Carriers: A Single-Center Observational Study. Anticancer Drugs 2019, 30, 410-415. [CrossRef]

40. Negarandeh, R.; Salehifar, E.; Saghafi, F.; Jalali, H.; Janbabaei, G.; Abdhaghighi, M.J.; Nosrati, A. Evaluation of Adverse Effects of Chemotherapy Regimens of 5-Fluoropyrimidines Derivatives and Their Association with DPYD Polymorphisms in Colorectal Cancer Patients. BMC Cancer 2020, 20, 560. [CrossRef]

41. Pallet, N.; Hamdane, S.; Garinet, S.; Blons, H.; Zaanan, A.; Paillaud, E.; Taieb, J.; Laprevote, O.; Loriot, M.-A.; Narjoz, C. A Comprehensive Population-Based Study Comparing the Phenotype and Genotype in a Pretherapeutic Screen of Dihydropyrimidine Dehydrogenase Deficiency. Br. J. Cancer 2020. [CrossRef]

42. European Medicines Agency Home Page. Available online: https://www.ema.europa.eu/en/medicines/ human/referrals/fluorouracil-fluorouracil-related-substances-capecitabine-tegafur-flucytosine-containingmedicinal (accessed on 30 April 2020).

43. European Medicines Agency Home Page. Available online: https://www.ema.europa.eu/en/documents/ referral/fluorouracil-fluorouracil-related-substances-article-31-referral-ema-recommendations-dpdtesting_en.pdf (accessed on 15 July 2020).

44. Froehlich, T.K.; Amstutz, U.; Aebi, S.; Joerger, M.; Largiadèr, C.R. Clinical Importance of Risk Variants in the Dihydropyrimidine Dehydrogenase Gene for the Prediction of Early-Onset Fluoropyrimidine Toxicity. Int. J. Cancer 2015, 136, 730-739. [CrossRef]

45. Toffoli, G.; Giodini, L.; Buonadonna, A.; Berretta, M.; De Paoli, A.; Scalone, S.; Miolo, G.; Mini, E.; Nobili, S.; Lonardi, S.; et al. Clinical Validity of a DPYD-Based Pharmacogenetic Test to Predict Severe Toxicity to Fluoropyrimidines. Int. J. Cancer 2015, 137, 2971-2980. [CrossRef]

46. Meulendijks, D.; Jacobs, B.A.W.; Aliev, A.; Pluim, D.; van Werkhoven, E.; Deenen, M.J.; Beijnen, J.H.; Cats, A.; Schellens, J.H.M. Increased Risk of Severe Fluoropyrimidine-Associated Toxicity in Patients Carrying a G to C Substitution in the First 28-Bp Tandem Repeat of the Thymidylate Synthase 2R Allele. Int. J. Cancer 2016, 138, 245-253. [CrossRef] [PubMed]

47. European Medicines Agency Home Page. Available online: https:/www.ema.europa.eu/en/documents/ product-information/erbitux-epar-product-information_it.pdf (accessed on 1 August 2020).

48. European Medicines Agency Home Page. Available online: https://www.ema.europa.eu/documents/ overview/avastin-epar-summary-public_it.pdf (accessed on 1 August 2020).

49. Agenzia Italiana del Farmaco Home Page. Available online: https:/farmaci.agenziafarmaco.gov. it/aifa/servlet/PdfDownloadServlet\%3FpdfFileName\%3Dfooter_003142_039170_RCP.pdf\%26retry\% 3D0\%26sys\%3Dm0b113\&ved=2ahUKEwicnenw0MrrAhVI-aQKHc9iAT0QFjADegQIBBAB\&usg= AOvVaw302NVA85pxPclL8QoyfW-R\&cshid=1599056097201 (accessed on 1 August 2020).

50. European Medicines Agency Home Page. Available online: https://www.ema.europa.eu/en/documents/ product-information/onivyde-pegylated-liposomal-epar-product-information_it.pdf (accessed on 1 August 2020).

51. Toffoli, G.; De Mattia, E. Pharmacogenetic Relevance of MTHFR Polymorphisms. Pharmacogenomics 2008, 9 , 1195-1206. [CrossRef] [PubMed] 
52. Zhong, L.; He, X.; Zhang, Y.; Chuan, J.-L.; Chen, M.; Zhu, S.-M.; Peng, Q. Relevance of Methylenetetrahydrofolate Reductase Gene Variants C677T and A1298C with Response to Fluoropyrimidine-Based Chemotherapy in Colorectal Cancer: A Systematic Review and Meta-Analysis. Oncotarget 2018, 9, 31291-31301. [CrossRef] [PubMed]

53. Lecomte, T.; Landi, B.; Beaune, P.; Laurent-Puig, P.; Loriot, M.-A. Glutathione S-Transferase P1 Polymorphism (Ile105Val) Predicts Cumulative Neuropathy in Patients Receiving Oxaliplatin-Based Chemotherapy. Clin. Cancer Res. Off. J. Am. Assoc. Cancer Res. 2006, 12, 3050-3056. [CrossRef] [PubMed]

54. Liu, Y.-P.; Ling, Y.; Qi, Q.-F.; Zhang, Y.-P.; Zhang, C.-S.; Zhu, C.-T.; Wang, M.-H.; Pan, Y.-D. Genetic Polymorphisms of ERCC1-118, XRCC1-399 and GSTP1-105 Are Associated with the Clinical Outcome of Gastric Cancer Patients Receiving Oxaliplatin-based Adjuvant Chemotherapy. Mol. Med. Rep. 2013, 7, 1904-1911. [CrossRef]

55. Lv, F.; Ma, Y.; Zhang, Y.; Li, Z. Relationship between GSTP1 Rs1695 Gene Polymorphism and Myelosuppression Induced by Platinum-Based Drugs: A Meta-Analysis. Int. J. Biol. Markers 2018, 33, 364-371. [CrossRef]

56. Peng, Z.; Wang, Q.; Gao, J.; Ji, Z.; Yuan, J.; Tian, Y.; Shen, L. Association between GSTP1 Ile105Val Polymorphism and Oxaliplatin-Induced Neuropathy: A Systematic Review and Meta-Analysis. Cancer Chemother. Pharmacol. 2013, 72, 305-314. [CrossRef]

57. Hamzic, S.; Kummer, D.; Froehlich, T.K.; Joerger, M.; Aebi, S.; Palles, C.; Thomlinson, I.; Meulendijks, D.; Schellens, J.H.M.; García-González, X.; et al. Evaluating the Role of ENOSF1 and TYMS Variants as Predictors in Fluoropyrimidine-Related Toxicities: An IPD Meta-Analysis. Pharmacol. Res. 2020, 152, 104594. [CrossRef]

58. Gallegos-Arreola, M.P.; Zúñiga-González, G.M.; Sánchez-López, J.Y.; Cruz, A.Y.N.; Peralta-Leal, V.; Figuera, L.E.; Puebla-Pérez, A.M.; Ronquillo-Carreón, C.A.; Puebla-Mora, A.G. TYMS 2R3R Polymorphism and DPYD [IVS]14+1G > A Gene Mutation in Mexican Colorectal Cancer Patients. Acta Biochim. Pol. 2018, 65, 227-234. [CrossRef] [PubMed]

59. Gamelin, E.C.; Danquechin-Dorval, E.M.; Dumesnil, Y.F.; Maillart, P.J.; Goudier, M.J.; Burtin, P.C.; Delva, R.G.; Lortholary, A.H.; Gesta, P.H.; Larra, F.G. Relationship between 5-Fluorouracil (5-FU) Dose Intensity and Therapeutic Response in Patients with Advanced Colorectal Cancer Receiving Infusional Therapy Containing 5-FU. Cancer 1996, 77, 441-451. [CrossRef]

60. Chazal, M.; Etienne, M.C.; Renée, N.; Bourgeon, A.; Richelme,H.; Milano, G. Link between Dihydropyrimidine Dehydrogenase Activity in Peripheral Blood Mononuclear Cells and Liver. Clin. Cancer Res. 1996, 2, 507-510. [PubMed]

61. Gamelin, E.; Boisdron-Celle, M.; Guérin-Meyer, V.; Delva, R.; Lortholary, A.; Genevieve, F.; Larra, F.; Ifrah, N.; Robert, J. Correlation between Uracil and Dihydrouracil Plasma Ratio, Fluorouracil (5-FU) Pharmacokinetic Parameters, and Tolerance in Patients with Advanced Colorectal Cancer: A Potential Interest for Predicting 5-FU Toxicity and Determining Optimal 5-FU Dosage. J. Clin. Oncol. 1999, 17, 1105-1110. [CrossRef] [PubMed]

62. Thomas, F.; Hennebelle, I.; Delmas, C.; Lochon, I.; Dhelens, C.; Tixidre, C.G.; Bonadona, A.; Penel, N.; Goncalves, A.; Delord, J.P.; et al. Genotyping of a Family with a Novel Deleterious DPYD Mutation Supports the Pretherapeutic Screening of DPD Deficiency with Dihydrouracil/Uracil Ratio. Clin. Pharmacol. Ther. 2016, 99, 235-241. [CrossRef]

(C) 2020 by the authors. Licensee MDPI, Basel, Switzerland. This article is an open access article distributed under the terms and conditions of the Creative Commons Attribution (CC BY) license (http://creativecommons.org/licenses/by/4.0/). 